\title{
Spatial and temporal patterns of colonization by deep-sea hydrothermal vent invertebrates on the Juan de Fuca Ridge, NE Pacific
}

\author{
Noreen Kelly ${ }^{1, *}$, Anna Metaxas ${ }^{1}$, David Butterfield ${ }^{2}$ \\ ${ }^{1}$ Department of Oceanography, Dalhousie University, 1355 Oxford St., Halifax, Nova Scotia B3H 4J1, Canada \\ ${ }^{2}$ Pacific Marine Environmental Laboratory (PMEL)/NOAA, 7600 Sand Point Way NE, Bin C15700, Seattle, \\ Washington 98115-0070, USA
}

\begin{abstract}
This study quantifies patterns in settlement and colonization of hydrothermal vent invertebrates and explores relationships with the biotic and abiotic factors that may influence these patterns. Colonization was measured between 2001 and 2003 in 2 segments of the Juan de Fuca Ridge, by deploying sets of basalt blocks at vents with different flow characteristics, over different spatial (cm to $100 \mathrm{~km}$ ) and temporal (1 to $2 \mathrm{yr}$ ) scales. Spatial variation in colonization was greater between vents within a segment ( $\mathrm{m}$ to $\mathrm{km}$ scale) than between segments, which we suggest reflects a species-specific response to varying environmental conditions at a particular vent. For gastropods, gregarious settlement enhanced colonization, while post-settlement mortality influenced colonization patterns of polychaetes. In 2003, we characterized the spatial variability in environmental conditions among 3 vent sites, through discrete in situ measures of the temperature and chemical properties of venting fluid near basalt blocks. Most colonist and settler abundances were positively correlated with vent fluid properties, notably dissolved $\mathrm{H}_{2} \mathrm{~S}$ and temperature. Our results suggest that the variation in settlement and colonization of hydrothermal vent species is mainly influenced by the properties of the vent fluid, but biological interactions can also have a significant influence on colonization processes. Our study is the first to experimentally quantify colonization by invertebrates at Juan de Fuca Ridge vent sites, and extends the understanding of the role of physical and biological factors in the regulation of early life-history stages.
\end{abstract}

KEY WORDS: Colonization · Settlement $\cdot$ Hydrothermal vent $\cdot$ Post-settlement mortality $\cdot$ Gregarious settlement $\cdot$ Temperature $\cdot$ Dissolved sulphide $\cdot$ Juan de Fuca Ridge

\section{INTRODUCTION}

Hydrothermal vents are model systems to study processes that regulate population dynamics, as they are amongst the most geologically dynamic regions on earth, and community extinctions and rebirths are common. Additionally, these regions are fragmented, as individual areas of active venting are often separated by hundreds of kilometres along the mid-ocean ridges. Dense invertebrate populations are maintained through the dispersal of larvae that must be able to cover great distances, find suitable substrates for settlement and recruit successfully. Thus, colonization is thought to be the consequence of a combination of the life-history strategies of different species, the physical oceanographic processes affecting dispersal, biological interactions, and species responses to the dynamic hydrothermal environment (Lutz et al. 1980, Shank et al. 1998).

Invertebrate populations inhabiting hydrothermal vent habitats ultimately depend on the properties of the vent fluid for survival and growth, since reactions between vent fluids and oxygenated seawater provide the energy for chemosynthetic microbes (symbiotic and free-living) that are the primary producers of the ecosystem (Karl et al. 1980, Jannasch 1995, Tunnicliffe et al. 1997). Vent faunal species frequently experience large gradients in the physico-chemical conditions of the vent fluid that can vary over short time scales (hours 
to days) (Johnson et al. 1986, 1988a, Chevaldonne et al. 1991, Sarrazin et al. 1997), as well as frequent disturbance, chimney collapse or volcanic eruption (Tunnicliffe \& Juniper 1990, Sarrazin et al. 1999). Consequently, environmental conditions have been considered the main factor regulating community structure at hydrothermal vents, and biological interactions can only influence this structure within the constraints imposed by environmental factors (Sarrazin et al. 1999, Luther et al. 2001). For example, changes in community structure coincide with disturbance events (local perturbations or eruptions), and consequent modifications in hydrothermal fluid flow (cessation or local reactivation) over sub-annual and/or sub-decadal time scales (Tunnicliffe \& Juniper 1990, Sarrazin et al. 1997, Shank et al. 1998). However, several studies have suggested that biological interactions, such as competition, facilitation, predation and grazing, also contribute to the regulation of macrofaunal invertebrate populations (Van Dover et al. 1988, Tunnicliffe \& Juniper 1990, Sarrazin et al. 1997, Tunnicliffe et al. 1997, Mullineaux et al. 2000, Micheli et al. 2002, Hunt et al. 2004).

Few studies to date have examined the importance of variation in settlement and recruitment at hydrothermal vents, due to the relative inaccessibility and current technological and logistical constraints of conducting manipulative experiments in these locations. Further, relationships between faunal distributions and the chemistry and temperature of hydrothermal vents has been explored in less than a handful of sites. Thus, it is unknown whether the same factors influence community structure of adults and earlier lifehistory stages. Van Dover et al. (1988) found that total recruitment was higher in active regions of vents, suggesting these conditions were most conducive to settlement and/or early survival of vent fauna. Mullineaux et al. (2003) showed that negative biological interactions were most prominent at vents where the fluid flux and faunal densities were highest, while positive interactions occurred at the low end of the fluid flux gradient where faunal densities were lower. However, measures of recruitment taken with coincident measures of temperature or chemical vent fluid composition are currently lacking.

In this study, we quantified settlement and colonization of invertebrates in hydrothermal vent habitats and identified biotic and abiotic factors in these habitats that may influence the patterns of settlement and colonization on the Juan de Fuca Ridge. Specifically, we used basalt blocks deployed at hydrothermal vents, at different spatial (cm to $100 \mathrm{~km}$ ) and temporal (1 to $2 \mathrm{yr}$ ) scales, to quantify patterns and the sources of variation in settlement and colonization. We measured the temperature and chemical properties of venting fluid at these sites to examine the influence of fluid properties on colonization and settlement. Also, we used sequential and overlapping deployment periods of basalt blocks to identify potential intra-specific interactions that may regulate colonist abundances. This is the first study to experimentally quantify invertebrate colonization at Juan de Fuca Ridge hydrothermal vents.

\section{MATERIALS AND METHODS}

Study sites. The Juan de Fuca Ridge (JdFR) in the Northeast Pacific is located 400 to $500 \mathrm{~km}$ off the northwest coast of North America, at the junction of the Pacific and Juan de Fuca tectonic plates (from 44.5 to $48^{\circ} \mathrm{N}$ ) (Lavelle \& Cannon 2001). This study was conducted at 2 ridge segments separated by $\sim 200 \mathrm{~km}$ : Axial Volcano off the Oregon Coast $\left(46^{\circ} \mathrm{N}, 130^{\circ} \mathrm{W}\right.$; depth ca. $\left.1400 \mathrm{~m}\right)$, and the Endeavour segment off the west coast of Vancouver Island $\left(48^{\circ} \mathrm{N}, 129^{\circ} \mathrm{W}\right.$; depth ca. $\left.2200 \mathrm{~m}\right)$. Colonization experiments were conducted at 2 vent sites within each ridge segment: (1) at Axial Volcano, the ROPOS vent site within the ASHES vent field $\left(45^{\circ} 55^{\prime} 59^{\prime \prime} \mathrm{N}\right.$, $130^{\circ} 0^{\prime} 51^{\prime \prime} \mathrm{W}$ ), and Cloud vent site ('Cloud ${ }_{\text {near' }}$ : directly at the venting orifice; 'Cloud $\mathrm{far}^{\prime} 8 \mathrm{~m}$ away) located in the South Rift Zone (SRZ; 46 56' 00" N, 129 58' 53" W); and (2) at the Endeavour Segment, the Clam Bed vent site $\left(47^{\circ} 57^{\prime} 47^{\prime \prime} \mathrm{N}, 129^{\circ} 5^{\prime} 19^{\prime \prime} \mathrm{W}\right)$, and the Smoke and Mirrors (SM) vent site, in the Main Endeavour field $\left(47^{\circ} 56^{\prime} 54^{\prime \prime} \mathrm{N}, 129^{\circ} 05^{\prime} 54^{\prime \prime} \mathrm{W}\right)$ (Table 1, Fig. 1). Within each segment, pairs of vent sites are separated by $\sim 2 \mathrm{~km}$.

The terminology defined by Zal et al. (1995) is used to describe the hierarchical levels of hydrothermal vent distribution throughout the JdFR. 'Vent' refers to a single, localized emission of hydrothermal fluid; 'vent site' refers to a spatially continuous venting area containing several vent emissions (m scale) that are linked by subterranean ducts; a 'vent field' is a cluster of vent sites (100 m scale) undergoing the same temporal variations; and 'vent sectors' are the largest spatial units, corresponding to oceanic ridge segments (10 - 100s km scale).

Chemical characteristics of the vent sites. In 2003, discrete in situ measures of the temperature and chemical properties of venting fluid, were taken at Cloud, Clam Bed, and SM vent sites. Vent water samples were collected with titanium major samplers and with the Hydrothermal Fluid and Particle Sampler (HFPS) (Butterfield et al. 2004), and processed and analyzed as described in Lilley et al. (1993) and Butterfield et al. (1994, 2004). Total hydrogen sulphide (5\% 2-sigma precision) and dissolved silicate (1\%) were measured colorimetrically on board ship. Magnesium (0.5\%), total dissolved iron (5\%) and manganese $(5 \%)$ were measured on shore.

Concentrations of chemical species in hydrothermal fluids are highly correlated with fluid temperature. 
Table 1. Location, position, depth, year of deployment, and length of deployment of basalt blocks. Temperature $(T)$ was measured at the level of the basalt blocks at time of recovery (maximum above ambient: Axial $=2.2^{\circ} \mathrm{C}_{;}$Endeavour $=1.9^{\circ} \mathrm{C}$ ). nd: no data (not measured). SRZ: South Rift Zone; MEF: Main Endeavour Field; ASHES: Axial Seamount Hydrothermal Emissions Study vent field

\begin{tabular}{|c|c|c|c|c|c|c|c|}
\hline $\begin{array}{l}\text { Ridge/ } \\
\text { Segment }\end{array}$ & Vent field & Vent site & Lat./long. & Depth (m) & $\begin{array}{l}\text { Deployment } \\
\text { period }\end{array}$ & $\begin{array}{l}\text { Length of } \\
\text { deployment } \\
\text { (d) }\end{array}$ & $\begin{array}{c}T \\
\left({ }^{\circ} \mathrm{C}\right)\end{array}$ \\
\hline Axial Volcano & ASHES & ROPOS & $\begin{array}{c}45^{\circ} 55^{\prime} 59^{\prime \prime} \mathrm{N} \\
/ 130^{\circ} 00^{\prime} 50^{\prime \prime} \mathrm{W}\end{array}$ & 1550 & $\begin{array}{l}2001-2002 \\
2002-2003 \\
2001-2003\end{array}$ & $\begin{array}{l}362 \\
409 \\
762\end{array}$ & $\begin{array}{l}\text { nd } \\
8.5 \\
3.5\end{array}$ \\
\hline & SRZ & Cloud $_{\text {near }}$ & $\begin{array}{c}45^{\circ} 56^{\prime} 00^{\prime \prime} \mathrm{N} \\
/ 129^{\circ} 58^{\prime} 53^{\prime \prime} \mathrm{W}\end{array}$ & 1525 & $\begin{array}{l}2001-2002 \\
2002-2003 \\
2001-2003\end{array}$ & $\begin{array}{l}354 \\
410 \\
764\end{array}$ & $\begin{array}{c}5.8 \\
5 \\
1\end{array}$ \\
\hline & & Cloud $_{\text {far }}$ & & 1525 & $\begin{array}{l}2001-2002 \\
2001-2003\end{array}$ & $\begin{array}{l}354 \\
764\end{array}$ & $\begin{array}{l}0 \\
0\end{array}$ \\
\hline $\begin{array}{l}\text { Endeavour } \\
\text { segment }\end{array}$ & $\begin{array}{c}500 \mathrm{~m} \mathrm{~S} \text { of } \\
\text { High Rise } \\
\text { MEF }\end{array}$ & $\begin{array}{l}\text { Clam Bed } \\
\text { Smoke and } \\
\text { Mirrors }\end{array}$ & $\begin{array}{c}47^{\circ} 57^{\prime} 47^{\prime \prime} \mathrm{N} \\
/ 129^{\circ} 05^{\prime} 19^{\prime \prime} \mathrm{W} \\
47^{\circ} 56^{\prime} 54^{\prime \prime} \mathrm{N} \\
/ 129^{\circ} 05^{\prime} 19^{\prime \prime} \mathrm{W}\end{array}$ & $\begin{array}{l}2190 \\
2200\end{array}$ & $\begin{array}{l}2002-2003 \\
2001-2003 \\
2002-2003 \\
2001-2003\end{array}$ & $\begin{array}{l}357 \\
822 \\
350 \\
815\end{array}$ & $\begin{array}{c}\text { nd } \\
6 \\
\text { nd } \\
3\end{array}$ \\
\hline
\end{tabular}

Because we compare vents with a wide range in temperature, we measured vent fluid properties that reflected both the intensity of venting (e.g. maximum temperature) and those largely independent of mixing or intensity (e.g. ratio of dissolved Si or Mn to heat content). Additionally, $\mathrm{H}_{2} \mathrm{~S}$ and $\mathrm{Fe}$ are affected by hightemperature processes and by precipitation and redox reactions in the shallow mixing zone supplying lowtemperature vents, producing strong water column signals proximal to vent sites, and are biologically important as the substrates for chemosynthesis for free-living or symbiotic micro-organisms.

Excess chemical properties (measured concentration background concentration) were normalized to heat content [heat capacity $\times($ vent temperature - background seawater temperature)] of vent fluid $\left(\mu \mathrm{mol} \mathrm{kJ}{ }^{-1}\right)$. Using heat-normalized chemical properties provides a better measure of the underlying chemical character of the venting fluid, rather than the amount of mixing taking place during sampling. This method is also more
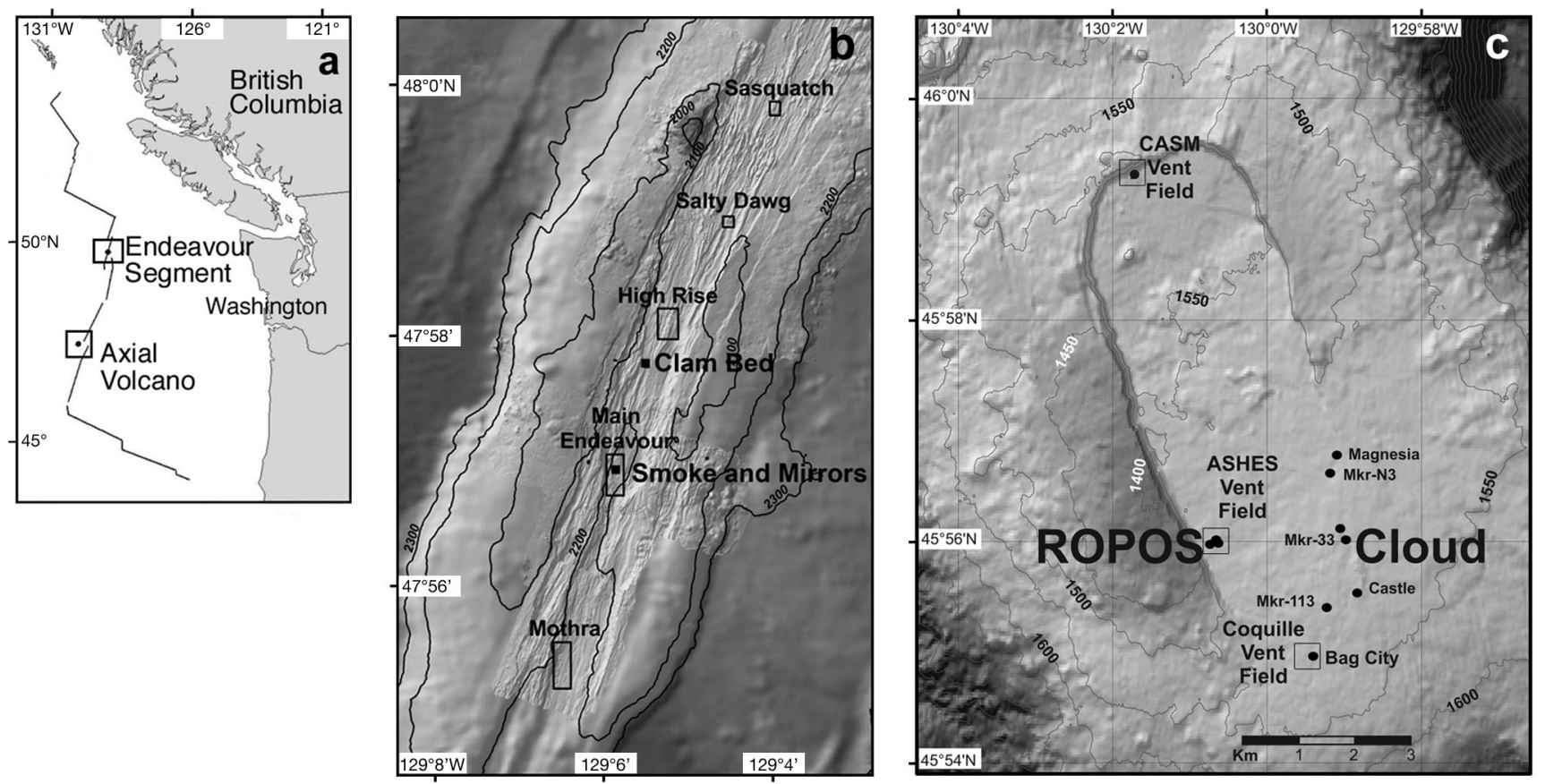

Fig. 1. (a) Location of Juan de Fuca Ridge, showing positions of Axial Volcano and Endeavour Segment. (b) Endeavour Segment, showing locations of Clam Bed and Smoke and Mirrors vent sites. Adapted from Glickson et al. (2007). (c) Axial Volcano, showing positions of ROPOS and Cloud vent sites 
directly tied to the effective chemical/heat anomalies produced in the hydrothermal plume. Maximum vent temperature $\left({ }^{\circ} \mathrm{C}\right)$ was measured directly at exit point. For SM, which was sampled with a titanium major sampler, the highest temperature in the vent orifice measured near the time of sampling was combined with the end-member concentration (measured value extrapolated to zero $\mathrm{Mg}$ concentration to remove the entrained seawater component). For all other vents, the average chemical concentration measured and the corresponding average in-line fluid temperature anomaly recorded by HFPS during sampling were used to calculate the property-to-heat ratio directly.

Experimental design and sample collection. Colonization was measured between 2001 and 2003, on blocks made of solid basalt collected from a talus pile in Nova Scotia, Canada ( $\left.45^{\circ} 11^{\prime} 15^{\prime \prime} \mathrm{N}, 64^{\circ} 27^{\prime} 04^{\prime \prime} \mathrm{W}\right)$. Basalts were selected to maintain a similarity in surface roughness and cut to a standard size $(\sim 7 \times 10 \times 2 \mathrm{~cm})$. For ease of deployment and recovery with the remotely operated vehicle (ROV) 'ROPOS', blocks within a vent site were attached to a single galvanized steel frame with a $20 \mathrm{~cm}$ galvanized steel threaded rod and held in plastic containers with holes pierced on the underside allowing for the diffusion of fluid through (or around) the substrate. Blocks within each frame were not in contact, and thus provide independent replicates (Fig. 2). We attempted to manipulate access by grazers and immigrants. Smooth polyethylene tubes covering the rod allowed grazer access, whereas an inverted funnel filled with Tanglefoot ${ }^{\mathrm{TM}}$ (tree resin) in combination with the uncovered threaded rod prevented immigrants from accessing the substrate. The position of each block was assigned randomly within a frame. We did not detect a significant difference in the number of colonists between 'grazer access' treatments for any species. Thus, replicate blocks on a frame were pooled across these treatments for all other analyses.

Sets of basalt blocks were deployed in pairs in 2001 at each vent site (Table 1). For each vent site, one set was collected after $1 \mathrm{yr}$ (in 2002) and replaced with a set of clean, uncolonized blocks. All remaining blocks were collected after 2 yr (in 2003). While we were restricted to deployment periods of $1 \mathrm{yr}$ intervals, we argue that a year is a sufficient period to allow for multiple episodic settlement and colonization events to occur. A preliminary deployment of a set of blocks for 1 wk in 2001 at Axial Volcano yielded no settlers (A. Metaxas pers. obs.). Van Dover et al. (1988) found few recruits on hard blocks after $26 \mathrm{~d}$, but observed 'significant recruitment' after $260 \mathrm{~d}$. Thus, the temporal scale in our study maximizes the probability of colonization, although it does not allow for high temporal resolution of post-settlement interactions.

Due to inclement weather conditions at Endeavour during the 2002 cruise, the blocks were not recovered, but uncolonized blocks were deployed. Consequently, we do not have colonization data for 2001-2002 at Clam Bed and SM. Also, the loss of 3 basalt blocks at SM (2002-2003) and one block from ROPOS (2001-2002) reduced the number of replicates at these vent sites.

For recovery, each set of blocks was gently placed in a LEXAN lidded box $(\sim 80 \times 60 \times 35 \mathrm{~cm})$, previously positioned within 0.5 to $1 \mathrm{~m}$ of the frame on the ocean floor. On the underside of the box lid, a glued $5 \mathrm{~cm}$ layer of open cell foam ensured a snug fit, preventing the dislodgment of organisms from the blocks during transport. Upon recovery, individual blocks (and the corresponding section of foam overlying the block) were removed from the frame, frozen at $-80^{\circ} \mathrm{C}$ aboard

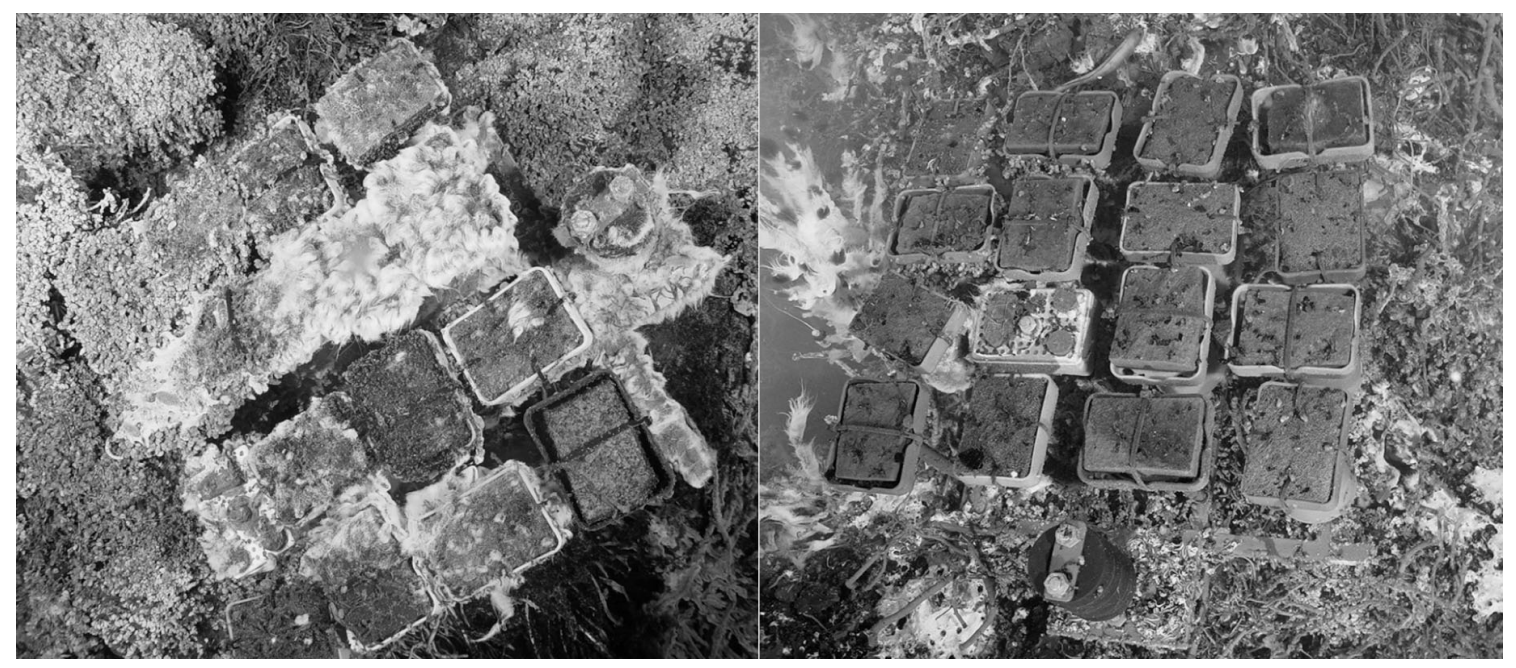

Fig. 2. In situ photographs of colonization substrates deployed on the Juan de Fuca Ridge from 2001-2003. Left panel: Clam Bed, Endeavour Segment; Right panel: Cloud vent (Cloud near $)$, Axial Volcano 
ship and then transferred into 95\% ethyl alcohol for long-term storage. Since knowledge of vent species biology is poor, and a conventional recruitment stage could not be identified for most species, we defined as colonists the accumulated number of post-larval staged individuals at the end of the recovery period of the blocks. All individuals on a block were enumerated and identified to the highest possible taxonomic resolution. Colonization was quantified for the 5 most abundant species (species containing $>10 \%$ of total numbers for $>50 \%$ of substrates) as abundance per unit surface area of basalt. Point measurements of fluid temperature $\left({ }^{\circ} \mathrm{C}\right.$ above ambient) were taken with the ROV 'ROPOS' temperature probe $\left( \pm 1^{\circ} \mathrm{C}\right)$ at the level of the blocks during recovery (Table 1 ).

Statistical analyses. To quantify the sources of both spatial and temporal variation, for the 5 most abundant species of colonists, we used the $1 \mathrm{yr}$ deployments (2001-2002 and 2002-2003) from Axial Volcano. Using MANOVA with factors Vent (fixed) and Year (random), spatial comparisons were made over 2 scales: (1) within each vent site at ROPOS, and Cloud $_{\text {near }}(\mathrm{cm}$ to $\mathrm{m}$ scale); and (2) among these vent sites within Axial Volcano ( $\mathrm{km}$ scale). Spatial comparisons were done over 3 scales, using a nested MANOVA design with Vent (random) nested within Segment (fixed) and the 20022003 and 2001-2003 deployments: (1) within ROPOS,

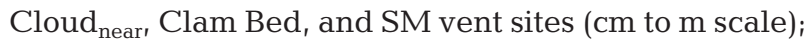
(2) between these vent sites within segments (ROPOS and Cloud $_{\text {near }}$ at Axial; Clam Bed and SM at Endeavour) (km scale); and (3) between segments (100 km scale). Prior to all analyses, colonization data were square-root transformed to remove heterogeneity of variances, as detected by Levene's test.

The effect of distance from venting on colonization was examined at Cloud vent site by comparing basalt blocks from Cloud $_{\text {near }}(<1 \mathrm{~m})$ and Cloud far $(10 \mathrm{~m})$ using 1-way MANOVA, with Distance as a fixed factor. Separate MANOVAs were done for the 2002-2003 (5 species) and 2001-2003 (6 species) deployment periods. Prior to analysis, colonization data were $\ln (\mathrm{x}+1)$-transformed to reduce heterogeneity of variances.

Settlement was quantified for 2 gastropod species, Lepetodrilus fucensis and Depressigyra globulus, by enumeration of individuals in the protoconch stage, defined as those that did not possess a post-larval shell. As for colonists, settlers were enumerated and quantified as abundance per unit surface area of basalt. Spatial and temporal patterns of gastropod settlers were analysed similarly to colonists, except using a nested ANOVA for each gastropod species instead of MANOVA. Prior to analysis, settler abundance was $\ln (\mathrm{x}+1)$-transformed to remove heterogeneity of variances. We did not observe larval stages of any other species on the basalt block surfaces.
For all MANOVAs, ANOVAs for each species were conducted if MANOVA indicated significant differences within species. Tukey's Honestly Significantly Difference (HSD) post-hoc tests were used to examine differences as detected by ANOVA. Where sample sizes were unbalanced, geometric instead of arithmetic means were used in post-hoc testing.

To explore the influence of intraspecific biological factors on colonization patterns, the sum of the colonists from the two 1 yr basalt blocks (consecutive) was compared to the single 2 yr colonization blocks (continuous) placed at the same vent site (as in Mullineaux et al. 2003). If the sum of the mean abundance of colonists on blocks in the 2 consecutive 1 yr deployments (20012002 plus 2002-2003) is not different than the abundance in the continuous 2 yr deployment (2001-2003), then colonization variability is mainly determined by processes affecting larvae in the plankton or at settlement, but not after settlement. This hypothesis serves as our null model. If the sum of the abundance of colonists in the consecutive deployments is significantly greater than the abundance in the continuous deployment, negative interactions such as post-settlement mortality are considered to be regulating colonization patterns. However, if the sum of the abundance of colonists in the consecutive deployments is lower than in the $2 \mathrm{yr}$ continuous deployment, then colonization variability is considered to be mainly regulated by positive interactions, such as gregarious settlement (i.e. larvae settle close to juveniles or adults). For each of the 5 most abundant species, one-sample $t$-tests were used to compare abundance of colonists on the blocks from the continuous 2 yr deployment to the sum of mean abundance in the two 1 yr deployments, for ROPOS and Cloud vent sites. To make these comparisons, we assumed there was no variation in initial settlement between paired block deployments at the same vent.

For 2 gastropod species, Lepetodrilus fucensis and Depressigyra globulus, the influence of neutral, positive and negative intraspecific effects were further explored by linear regression of number of settlers against number of colonists, for Cloud, ROPOS, and Clam Bed vent sites. SM vent site was not included, because of the low numbers of settlers collected. Prior to regression, abundances of settlers and colonists were $\ln (\mathrm{x}+1)$ transformed to remove heterogeneity of variances. If there is no relationship between colonization and settlement, larvae settle randomly relative to conspecifics.

\section{RESULTS}

A total of 27 taxa colonized the basalt blocks, but only 7 were present at all vents. The gastropod Lepetodrilus fucensis was the most abundant, while the gastropods 
Table 2. Mean abundance (per $100 \mathrm{~cm}^{2}$ ) \pm (SE) of taxa found on basalt blocks deployed from 2001-2002, 2002-2003, and 2001-2003 at ROPOS and Cloud vent sites (Axial Volcano), and Clam Bed and Smoke and Mirrors vent sites (Endeavour), along the Juan de Fuca Ridge, NE Pacific. n: no. of replicate basalt blocks in each vent site and deployment year

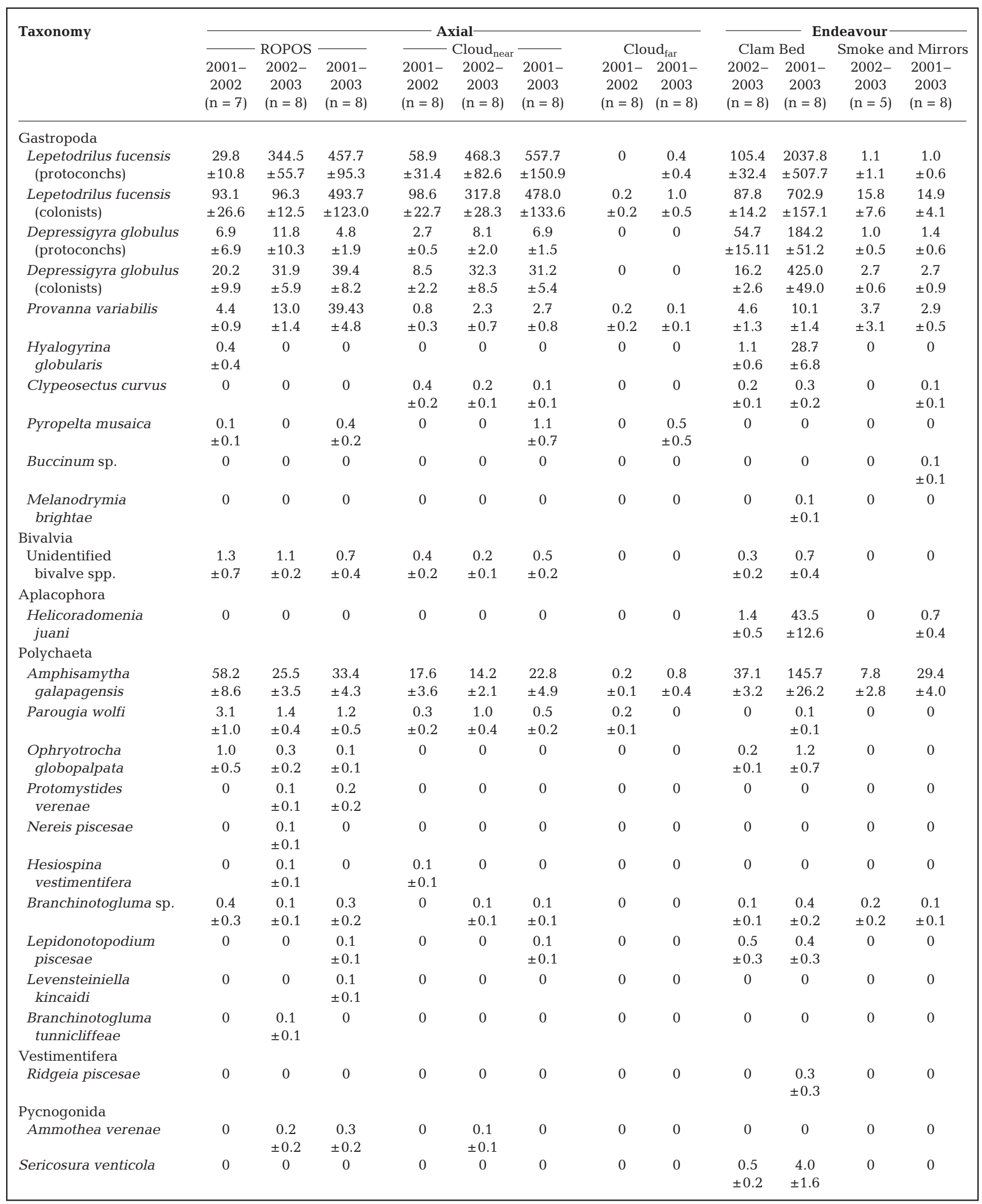


Table 2. (continued)

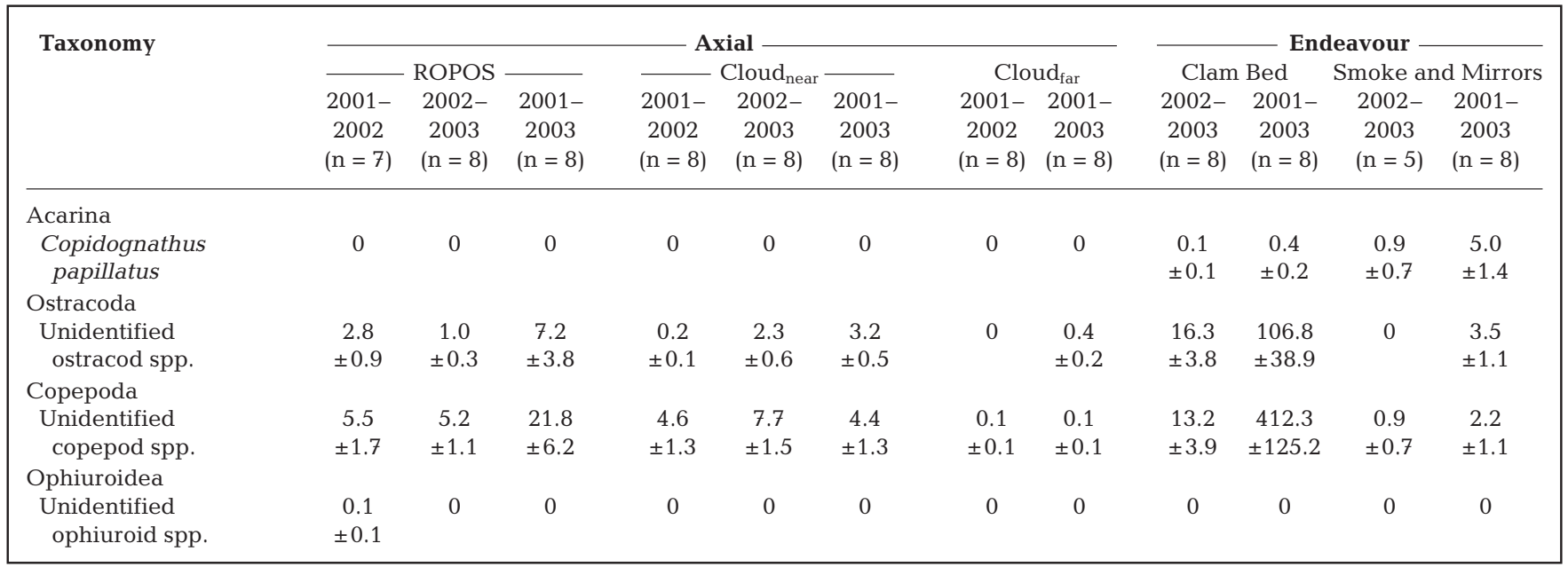

Depressigyra globulus and Provanna variabilis, and the polychaetes Amphisamytha galapagensis and Parougia wolfi, were also abundant, although usually one to two orders of magnitude less so than $L$. fucensis. Nine taxa were present at only 1 vent (Table 2 ). It is possible that a few individuals of mobile species may have migrated onto or away from the blocks during deployment. However, most mobile colonists recovered from the blocks were small, juvenile stages, implying their origin as settlement to the blocks rather than immigration. Species $>1.5 \mathrm{~mm}$ were easily viewed in digital images of block surfaces taken immediately prior to recovery. Of the species visible in digital images, counts of all individuals on blocks after recovery were higher than counts of all individuals in situ prior to recovery leading to the conclusion that few to no individuals were lost from the surfaces of the blocks, from all vents and deployment periods, during recovery.

\section{Patterns in settlement}

Gastropod settlement varied spatially and temporally for both Lepetodrilus fucensis and Depressigyra globulus (Fig. 3). At Axial Volcano, settlement of $L$. fucensis varied between years but not between vents, while settlement of $D$. globulus varied between vents and years (Fig. 3, Table 3). For both the 2002-2003 and 2001-2003 deployment periods at Axial and Endeavour, settlement of L. fucensis and D. globulus varied among vents within segments, but not among segments (Fig. 4, Table 4).

\section{Patterns in colonization}

At Axial Volcano, colonization varied spatially and temporally for 4 of the 5 most abundant species examined (Table 5). There were significant Vent $\times$ Year interactions for Lepetodrilus fucensis, Provanna variabilis, and Amphisamytha galapagensis (Fig. 5a). However, the pattern of variation between vents and years was not consistent among these 3 species (Fig. 5a, Table 5). L. fucensis colonist abundance was greatest at Cloud in 2002-2003, but was not different

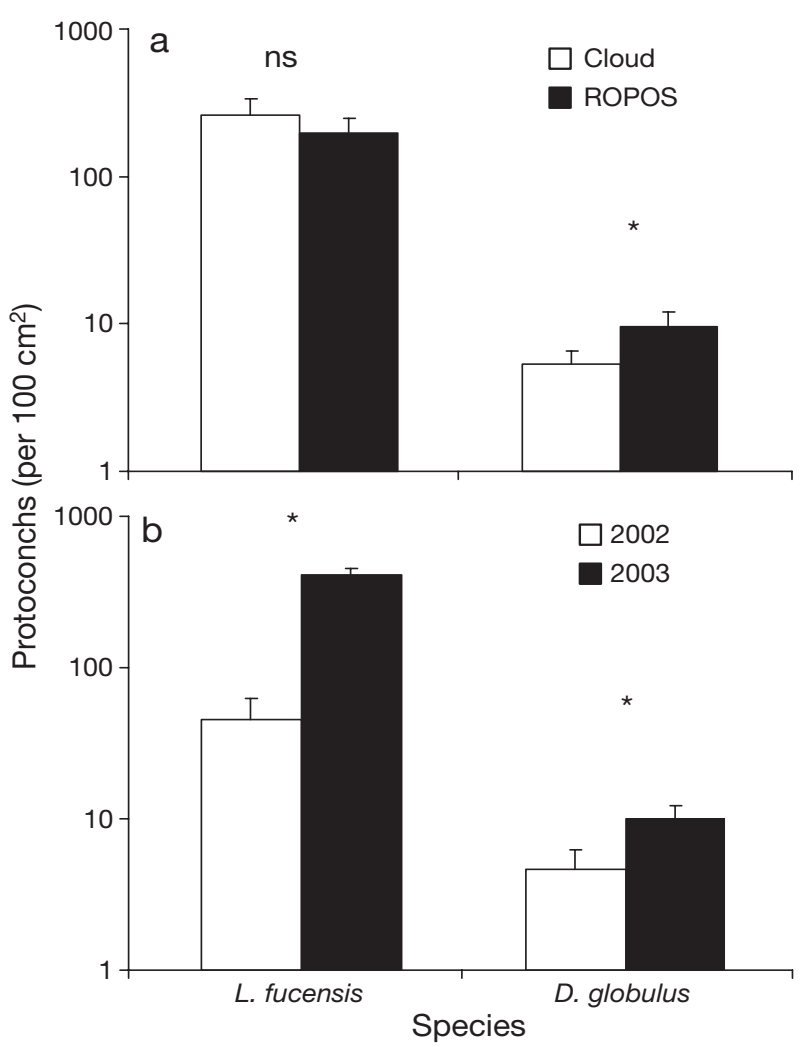

Fig. 3. Lepetodrilus fucensis and Depressigyra globulus. Abundance of settlers (mean + SE) on basalt blocks collected (a) from ROPOS and Cloud vent sites, Axial Volcano and (b) in 2002 and 2003. ns: no significant differences; (*) significant differences in settlement. $\mathrm{n}$ given in Table 2 
Table 3. Lepetodrilus fucensis and Depressigyra globulus. Fvalues of univariate analyses of variance (ANOVA) examining the spatial and temporal variation within a segment in settlement (no. of protoconchs) of L. fucensis and D. globulus between ROPOS and Cloud vent sites for the 2001-2002 and 2002-2003 deployment periods. df: degrees of freedom, ${ }^{*} \mathrm{p}<0.05,{ }^{* *} \mathrm{p}<0.01,{ }^{* * *} \mathrm{p}<0.001$

\begin{tabular}{|c|c|c|c|c|c|c|}
\hline \multirow{3}{*}{ Species } & \multirow{2}{*}{\multicolumn{2}{|c|}{ Vent }} & \multirow{2}{*}{\multicolumn{2}{|c|}{$\begin{array}{r}\text { Factor } \\
\text { Year }\end{array}$}} & \multirow{2}{*}{\multicolumn{2}{|c|}{ Vent $\times$ Year }} \\
\hline & & & & & & \\
\hline & $F$ & df & $F$ & df & $F$ & df \\
\hline L. fucensis & 3.01 & 1,1 & $55.97^{* * *}$ & 1,27 & 0.06 & 1,27 \\
\hline D. globulus & $196.0^{*}$ & 1,1 & $9.580^{* *}$ & 1,27 & 0.01 & 1,27 \\
\hline
\end{tabular}

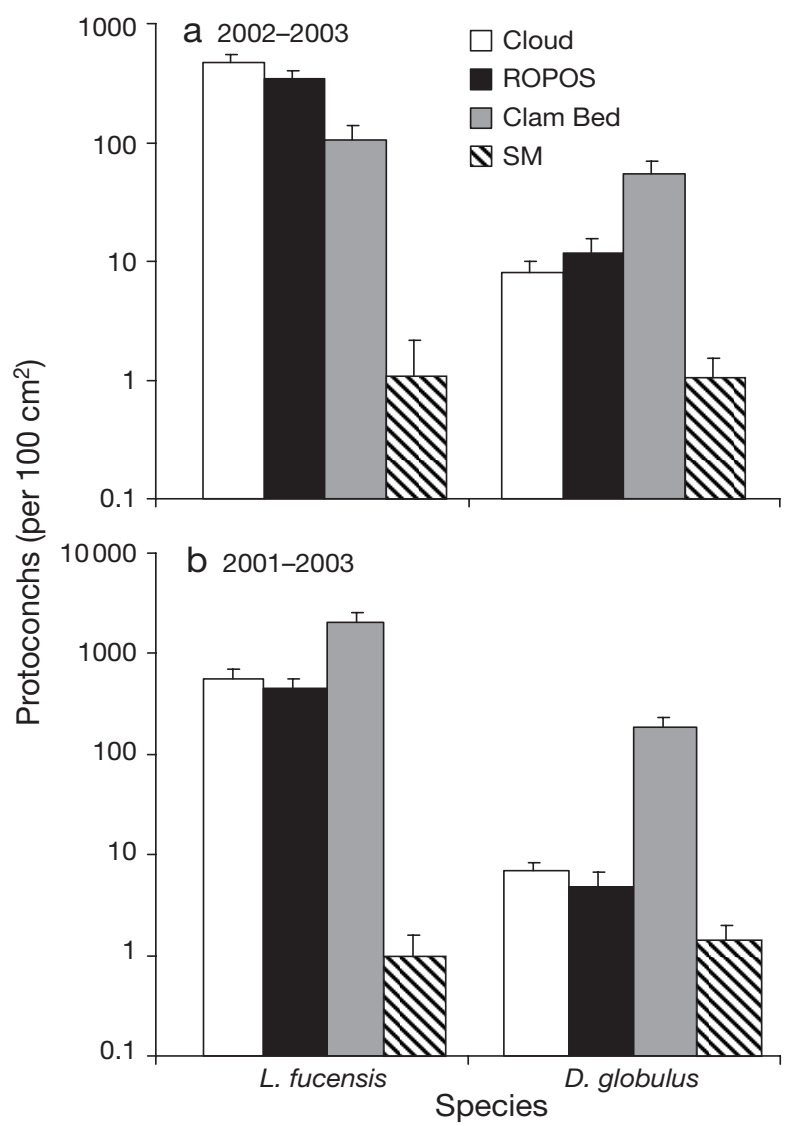

Fig. 4. Lepetodrilus fucensis and Depressigyra globulus. Abundance of settlers (mean $+\mathrm{SE}$ ) on basalt blocks deployed at vents sites at Axial Volcano: ROPOS, Cloud; and Endeavour segment: Clam Bed, Smoke and Mirrors (SM), collected in 2003 after (a) 1 yr (2002-2003) and (b) 2 yr deployment (2001-2003). n given in Table 2

at ROPOS between years, nor between ROPOS and Cloud in 2001-2002. For P. variabilis, colonist abundance did not vary between years at Cloud, but was greater in 2002-2003 than 2001-2002 at ROPOS, and was greater at ROPOS than at Cloud in both years. A. galapagensis colonist abundance was significantly greater at ROPOS than Cloud in both years, did not
Table 4. Lepetodrilus fucensis and Depressigyra globulus $F$-values of univariate analyses of variance (ANOVA) examining the sources for spatial variation between segments in settlement (no. of protoconchs) among ROPOS, Cloud, Clam Bed and Smoke and Mirrors vent sites within Axial and Endeavour segments for the 2002-2003 and 2001-2003 deployment periods. df: degrees of freedom; ${ }^{*} p<0.05,{ }^{* *} p<0.01$, ${ }^{* * *} \mathrm{p}<0.001$

\begin{tabular}{|c|c|c|c|c|c|}
\hline \multirow[t]{3}{*}{ Species } & \multirow{3}{*}{$\begin{array}{c}\text { Deployment } \\
\text { year }\end{array}$} & \multicolumn{4}{|c|}{ - Factor } \\
\hline & & \multicolumn{2}{|c|}{ Segment } & \multicolumn{2}{|c|}{ Vent (Segment) } \\
\hline & & $F$ & $\mathrm{df}$ & $F$ & df \\
\hline \multirow[t]{2}{*}{ L. fucensis } & $2002-2003$ & 2.753 & 1,2 & $41.21^{* * *}$ & 2,25 \\
\hline & 2001-2003 & 0.459 & 1,2 & $88.95^{* * *}$ & 2,28 \\
\hline \multirow[t]{2}{*}{ D. globulus } & $2002-2003$ & 0.048 & 1,2 & $33.51^{* * *}$ & 2,25 \\
\hline & 2001-2003 & 0.245 & 1,2 & $31.55^{* * *}$ & 2,28 \\
\hline
\end{tabular}

vary between years at Cloud, but was greater in 2001-2002 than 2002-2003 at ROPOS. For Depressigyra globulus and Parougia wolfi there were no significant interactions between Vent and Year. The abundance of $D$. globulus or $P$. wolfi colonists did not vary between ROPOS and Cloud in either year (Fig. 5b). Number of colonists of D. globulus was significantly greater in 2002-2003 than in 2001-2002, but there was no difference in the number of colonists of $P$. wolfi between years (Fig. 5b,c).

Abundance of the numerically dominant colonists varied spatially between vents within segments, but not between segments. For the 2002-2003 deployment period, there were significant effects both of Vent within Segment and between Segments (Table 6). For Lepetodrilus fucensis, Depressigyra globulus, Provanna variabilis, and Amphisamytha galapagensis, the numbers of colonists varied among vents within segments but not between segments, whereas the opposite was observed for Parougia wolfi (Fig. 6a, Table 6). Over the 2001-2003 deployment year, colonization also varied significantly between Segments, and among Vents within Segments (Fig 6b). However, nested ANOVA did not reveal a significant effect of segment for any species, and number of colonists varied with Vent within Segment for all species, except P. wolfi (Fig. 6b, Table 6).

Proximity to hydrothermal vent fluid at Cloud vent site had a significant effect on the number of colonists during both the 2001-2002 and 2001-2003 deployment periods (Table 7). Numbers of colonists was significantly greater at Cloud $_{\text {near }}$ than Cloud $_{\text {far }}$ locations for Lepetodrilus fucensis and Amphisamytha galapagensis in both 2001-2002 and 2001- 2003 (Fig. 7, Table 7). Neither Provanna variabilis nor Parougia wolfi showed differences in number of colonists with increasing distance from the vent source after 1 yr (2001-2002), but there was a significant dif- 


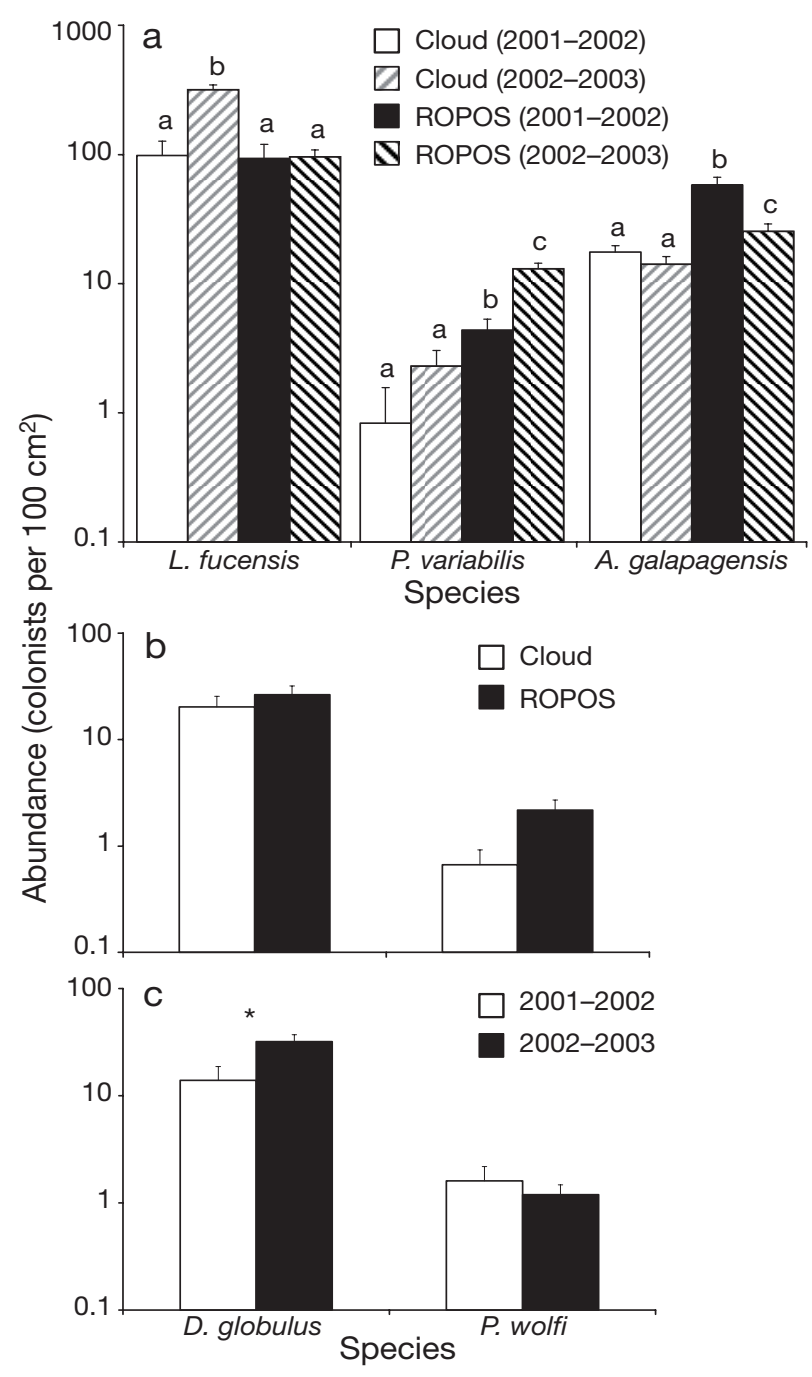

Fig. 5. (a) Lepetodrilus fucensis, Provanna variabilis and Amphisamytha galapagensis, (b) and (c) Depressigyra globulus and Parougia wolfi. Spatial and temporal variation in colonization abundance (mean + SE) for the 5 most abundant species found on basalt blocks deployed at ROPOS and Cloud vent, Axial Volcano, between 2001-2002 and 2002-2003 deployment periods. (a) Significant interactions between vent sites (ROPOS, Cloud) and deployment years (2001-2002 and 2002-2003). Different letters over bars indicate significant difference in colonization within a species (Tukey's HSD, $\mathrm{p}<0.05$ ). Abundance is pooled across (b) deployment years (2001-2002 and 2002-2003) and (c) vent sites (ROPOS, Cloud) because of the lack of a significant interaction. ${ }^{*}$ significant difference. $\mathrm{n}$ given in Table 2

ference after 2 yr (2001-2003). There was no significant difference in number of colonists of Pyropelta musaica between Cloud $_{\text {near }}$ and Cloud $_{\text {far }}$ in 2001-2003. Depressigyra globulus was only found at Cloud near $_{\text {dis- }}$ tances in both deployment periods (Fig. 7).

Variation in the composition of hydrothermal vent fluids was evident among 3 vent sites (Cloud, Clam
Table 5. Lepetodrilus fucensis, Provanna variabilis, Amphisamytha galapagensis, Depressigyra globulus and Parougia wolfi. $F$-values of MANOVA (Wilk's $\lambda$ ) and ANOVA examining the spatial and temporal variation in colonization of the 5 most abundant species among ROPOS and Cloud vent sites for the 2001-2002 and 2002-2003 deployment periods. All: MANOVA results; individual species: ANOVA results; df: degrees of freedom; ${ }^{*} \mathrm{p}<0.05,{ }^{* *} \mathrm{p}<0.01,{ }^{* * *} \mathrm{p}<0.001$

\begin{tabular}{|c|c|c|c|c|c|c|}
\hline \multirow{3}{*}{ Species } & \multirow{2}{*}{\multicolumn{2}{|c|}{ Vent }} & \multirow{3}{*}{$\begin{array}{c}\text { - Factor } \\
\text { Year }\end{array}$} & \\
\hline & & & & & & ear \\
\hline & $F$ & df & & df & F & $\mathrm{df}$ \\
\hline All & $19.52^{* * *}$ & 5,23 & $12.56^{* * *}$ & 5,23 & $5.18^{* *}$ & 5,23 \\
\hline L. fucensis & 1.221 & 1,1 & $18.47^{* * *}$ & 1,27 & $13.30^{* *}$ & 1,27 \\
\hline D. globulus & 1.702 & 1,1 & $10.48^{* *}$ & 1,27 & 0.372 & 1,27 \\
\hline P. variabilis & 8.739 & 1,1 & $23.98^{* * *}$ & 1,27 & $6.928^{*}$ & 1,27 \\
\hline A. galapagensis & 4.579 & 1,1 & $11.78^{* *}$ & 1,27 & $6.974^{*}$ & 1,27 \\
\hline P. wolfi & 2.145 & 1,1 & 0.231 & 1,1 & 4.150 & 1,27 \\
\hline
\end{tabular}

Table 6. Lepetodrilus fucensis, Provanna variabilis, Amphisamytha galapagensis, Depressigyra globulus and Parougia wolfi. $F$-values of significant MANOVA (Wilk's $\lambda$ ) and ANOVA examining the sources for spatial variation in colonization of the 5 most abundant species among ROPOS, Cloud, Clam Bed and Smoke and Mirrors vent sites within Axial and Endeavour segments for the 2002-2003 and 2001-2003 deployment periods. All: MANOVA results; individual species: ANOVA results; df: degrees of freedom;

$$
{ }^{*} \mathrm{p}<0.05,{ }^{* *} \mathrm{p}<0.01,{ }^{* * *} \mathrm{p}<0.001
$$

\begin{tabular}{|lcccc|}
\hline \multirow{2}{*}{ Species } & \multicolumn{4}{c}{ Factor } \\
\cline { 2 - 5 } & \multicolumn{2}{c}{ Segment } & \multicolumn{2}{c|}{ Vent (Segment) } \\
& $F$ & $\mathrm{df}$ & $F$ & $\mathrm{df}$ \\
\hline $\mathbf{2 0 0 2 - 2 0 0 3}$ & & & & \\
All & $19.92^{* * *}$ & 5,21 & $15.27^{* * *}$ & 10,42 \\
L. fucensis & 1.72 & 1,2 & $43.72^{* * *}$ & 2,25 \\
D. globulus & 4.87 & 1,2 & $4.13^{*}$ & 2,25 \\
$P$. variabilis & 0.31 & 1,2 & $12.38^{* * *}$ & 2,25 \\
A. galapagensis & 0.05 & 1,2 & $26.21^{* * *}$ & 2,25 \\
$P$. wolfi & $46.54 *$ & 1,2 & 0.47 & 2,25 \\
2001-2003 & & & & \\
All & $22.63^{* * *}$ & 5,24 & $39.23^{* * *}$ & 10,48 \\
L. fucensis & 0.34 & 1,2 & $18.69^{* * *}$ & 2,28 \\
D. globulus & 0.32 & 1,2 & $139.93^{* * *}$ & 2,28 \\
$P$. variabilis & 0.39 & 1,2 & $85.91^{* * *}$ & 2,28 \\
A. galapagensis & 1.08 & 1,2 & $22.95^{* * *}$ & 2,28 \\
$P$. wolfi & 6.84 & 1,2 & 1.29 & 2,28 \\
& & & & \\
\hline
\end{tabular}

Bed and SM) in 2003 (Table 8). For these vent sites, the abundances of Depressigyra globulus, Provanna variabilis, and Amphisamytha galapagensis colonists, and Lepetodrilus fucensis and D. globulus settlers, were positively correlated, while abundance of Parougia wolfi was negatively correlated, with most vent fluid properties (Table 9). 


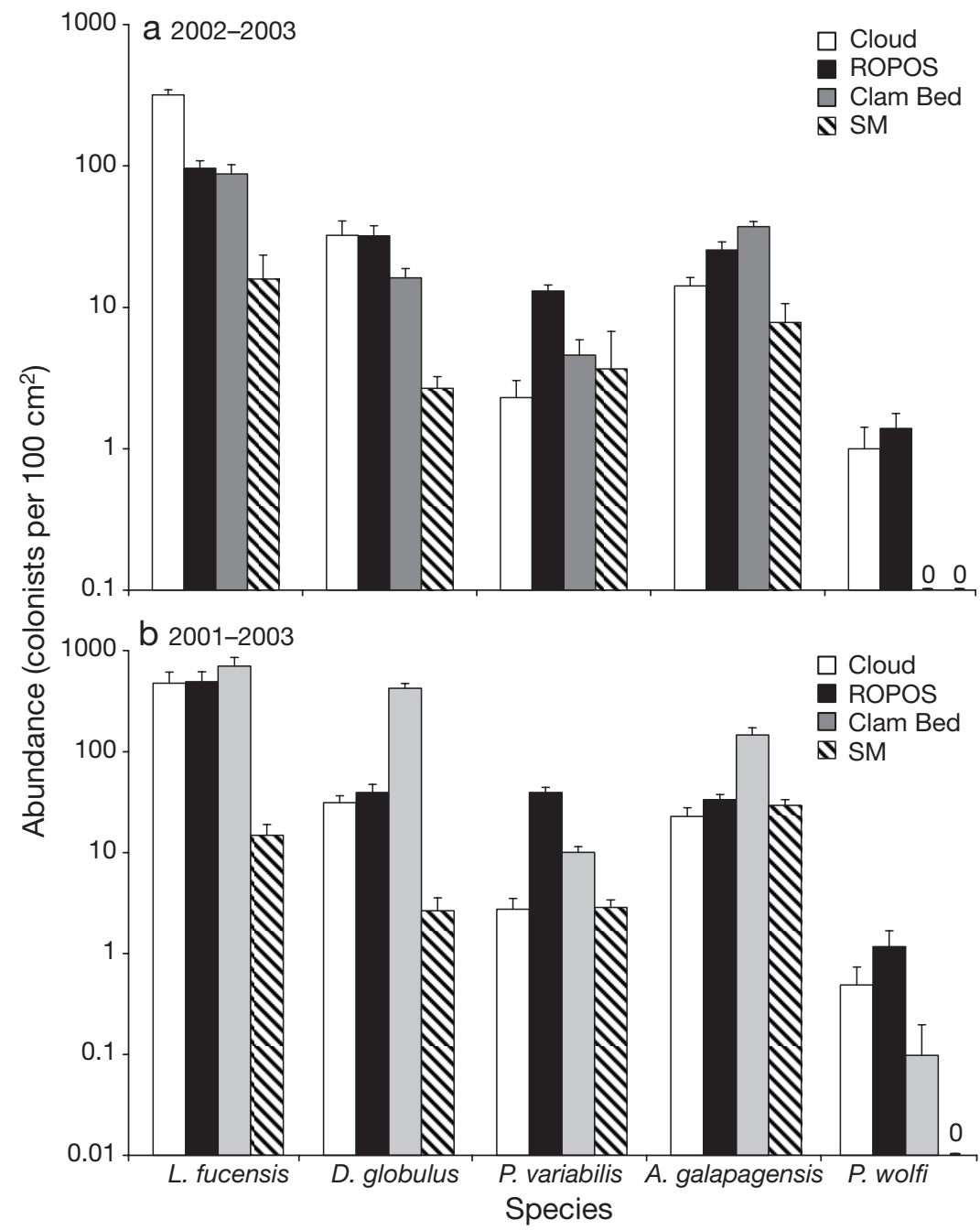

Fig. 6. Lepetodrilus fucensis, Provanna variabilis, Amphisamytha galapagensis, Depressigyra globulus and Parougia wolfi. Abundance of colonists (mean + SE) for the 5 most abundant species found on basalt blocks deployed at vents sites at Axial Volcano: ROPOS, Cloud; and Endeavour Segment: Clam Bed, Smoke and Mirrors (SM), for (a) the 2002-2003 deployment period and (b) for the 2001-2003 deployment period. $\mathrm{n}$ given in Table 2

\section{Intraspecific influences on colonization}

According to our hypotheses, positive intraspecific interactions were indicated if the sum of the mean abundance of colonists from the consecutive $1 \mathrm{yr}$ deployments was significantly lower than the mean abundance of colonists from the continuous 2 yr deployment. In contrast, if the summed abundance from the consecutive deployments was significantly greater than the continuous deployment, negative interactions were indicated in regulating colonization patterns. Neutral interactions, such that there was no significant different in the summed abundance from the consecutive deployments compared to the continuous deployment, served as our null model. Intraspecific interactions influenced the pattern of colo- nization of 4 of the 5 most abundant species at ROPOS, but not at Cloud vent site at Axial Volcano (Fig. 8, Table 10). At Cloud vent site, neutral interactions were indicated to be regulating the abundance of Lepetodrilus fucensis, Depressigyra globulus, Provanna variabilis, or Amphisamytha galapagensis colonists (Fig. 8a). In contrast, at ROPOS vent site, positive interactions were indicated for both $L$. fucensis and $P$. variabilis, a neutral interaction was indicated for D. globulus, and negative interactions indicated for A. galapagensis (Fig. 8b). Negative interactions were indicated for Parougia wolfi, at both Cloud and ROPOS vent sites.

For Lepetodrilus fucensis, there was a significant positive linear relationship between abundance of settlers and abundance of colonists for all vent sites tested (Fig. 9). For Depressigyra globulus, there was a significant positive linear relationship between settlers and colonists for Cloud, but not for ROPOS or Clam Bed (Fig. 9).

\section{DISCUSSION}

\section{Faunal composition}

Gastropods and polychaetes were the numerically dominant faunal groups that colonized basalt blocks at all vent sites over all deployment periods. These same taxa have also been documented in large abundances at Axial Volcano (Tsurumi \& Tunnicliffe 2003) and Endeavour (Sarrazin et al. 1999). In contrast to previous studies (Sarrazin \& Juniper 1999, Tsurumi \& Tunnicliffe 2001), we recorded more species recruiting to basalt blocks at Endeavour than at Axial Volcano, although there was much overlap in diversity (i.e. both segments had the same dominant species recruiting). Few to no individuals of Ridgeia piscesae or Paralvinella recruited, which are species typically abundant in diffuse flow habitats at Juan de Fuca vents (Tunnicliffe et al. 1993, Sarrazin \& Juniper 1999). While Van Dover et al. (1988) and Mullineaux et al. (1998) found very few vestimentiferan recruits on their basalt blocks, Mullineaux et al. $(2000,2003)$ and Hunt et al. (2004) observed large numbers of recruits after several months. However, Mullineaux et al. (1998) noticed that vestimentiferans only recruited to cracks 
Table 7. Lepetodrilus fucensis, Provanna variabilis, Amphisamytha galapagensis and Parougia wolfi. F-values of significant MANOVA (Wilk's $\lambda$ ) and ANOVA exploring differences in colonization between Cloud $_{\text {near }}$ and Cloud $_{\text {far }}$ locations at Cloud vent site, Axial Volcano, for 2 deployment periods, 2001-2002 and 2001-2003. Analyses were only conducted for species present at both locations. All: MANOVA results; individual species: ANOVA results; df: Degrees of freedom. ${ }^{*} \mathrm{p}<0.05,{ }^{* *} \mathrm{p}<0.01,{ }^{* * *} \mathrm{p}<0.001$

\begin{tabular}{|lcc|}
\hline Species & $F$ & $\mathrm{df}$ \\
& & \\
\hline 2001-2002 & & \\
All & $139.8^{* * *}$ & 5,10 \\
Lepetodrilus fucensis & $155.14^{* * *}$ & 1,14 \\
Provanna variabilis & 3.04 & 1,14 \\
Amphisamytha galapagensis & $108.17^{* * *}$ & 1,14 \\
Parougia wolfi & 0.15 & 1,14 \\
2001-2003 & & \\
All & $87.97^{* * *}$ & 4,9 \\
Lepetodrilus fucensis & $298.46^{* * *}$ & 1,14 \\
Amphisamytha galapagensis & $98.09^{* * *}$ & 1,14 \\
Pyropelta musaica & 0.96 & 1,14 \\
\hline
\end{tabular}

Table 8. Chemical variables $\left(\mathrm{H}_{2} \mathrm{~S}, \mathrm{Fe}, \mathrm{Mn}, \mathrm{Si}\right)$ and maximum temperature (Temp) measured in venting fluid at Cloud, Clam Bed, and Smoke and Mirrors (SM) vent sites in 2003 (Butterfield et al. 2004). Chemical variables are standardized per unit of heat of vent fluid $\left(\mu \mathrm{mol} \mathrm{kJ}{ }^{-1}\right)$; temperature in ${ }^{\circ} \mathrm{C}$

\begin{tabular}{|lccccc|}
\hline Vent site & $\mathrm{H}_{2} \mathrm{~S}$ & $\mathrm{Fe}$ & $\mathrm{Mn}$ & $\mathrm{Si}$ & Temp \\
\hline Cloud & 0.41 & 0.18 & 0.20 & 10.76 & 8.1 \\
Clam Bed & 12.83 & 2.19 & 1.82 & 48.01 & 41.6 \\
SM & 3.45 & 1.14 & 0.32 & 10.35 & 352.0 \\
\hline
\end{tabular}

and other cryptic habitats, or the underside of plates with direct access to fluids. These species may require specific conditions for successful colonization that were not met in our settling substrate environments.

\section{Spatial variation in settlement and colonization}

The differences in settler and colonist abundances were greater over small spatial scales ( $\mathrm{m}$ to $\mathrm{km}$ : within and among vents), than larger ones (100 km: among segments) for most species examined. Since the pattern of colonization differed among species, we suggest that this small-scale variation reflects a species-specific response to the varying environmental conditions at a particular vent. In a comparison of the faunal distributions in different vent segments across the Juan de Fuca Ridge, Tsurumi \& Tunnicliffe (2001) observed that it was the level of hydrothermalism rather than the geographic affinities of the vent sites that defined the faunal assemblages.
Settlement of the 2 most abundant gastropods, Lepetodrilus fucensis, and Depressigyra globulus, occurred at all vent sites at both segments in all deployment years. Settlement at all vents at the same time suggests that synchrony in gastropod settlement occurred on $\mathrm{km}$ scales within Axial Volcano and Endeavour. On the East Pacific Rise, Mullineaux et al. (1998) observed a settlement event of protoconchstaged L. elevatus on basalt plates separated as far as $1 \mathrm{~km}$. At Axial and Endeavour, a spatially homogeneous larval pool within the axial valleys (Metaxas 2004) would facilitate synchrony in settlement among spatially separated vent sites.

Temperature and dissolved $\mathrm{H}_{2} \mathrm{~S}$ were the vent fluid properties most consistently correlated with settler and colonist abundance across all species. Block temperature was positively correlated to abundance of all colonists except the predator Parougia wolfi, which may be influenced more by prey distribution than habitat characteristics. Temperature may act as a cue for colonists to locate preferred vent flows, or to minimize exposure to a combination of environmental stressors (Bates et al. 2005). $\mathrm{H}_{2} \mathrm{~S}$ has also been proposed as a chemical habitat cue, because sulphide oxidation is the dominant chemical energy source for microbial metabolism (Karl et al. 1980, Jannasch 1995). In our study, the majority of species colonizing basalt blocks were primary consumers of bacterial production, and the availability of $\mathrm{H}_{2} \mathrm{~S}$ in vent flows could reflect the availability of nutritional resources. At Endeavour vents, Rittschof et al. (1998) found vent polychaete post-larvae burrowed into filters containing $0.3 \mathrm{M}$ sulphide, whereas none colonized filters without sulphide. On sulphide edifices along the Juan de Fuca Ridge, $\mathrm{H}_{2} \mathrm{~S}$, but not temperature, was among the principal factors influencing adult distributions (Sarrazin et al. 1999). Environmental factors important in influencing faunal distributions may vary over the life history of a species.

Temperature could promote a major cue for settling larvae, indicating suitable habitats for settlement within a vent site. Larvae dispersing in currents or plumes (Mullineaux \& France 1995) would experience cold ambient temperatures, which are hypothesized to reduce their metabolic rates (Berg 1985). Temperature as a habitat cue is also the most parsimonious explanation, as encountering higher temperature buoyant hydrothermal fluids could invoke an instantaneous physiological response triggering settlement in dispersing larvae (Lutz et al. 1980). However, it is possible that hydrothermal species use multiple cues, such as temperature or chemical anomalies, to locate suitable vent habitats.

Our environmental measurements provide information on the physical and chemical characteristics of 


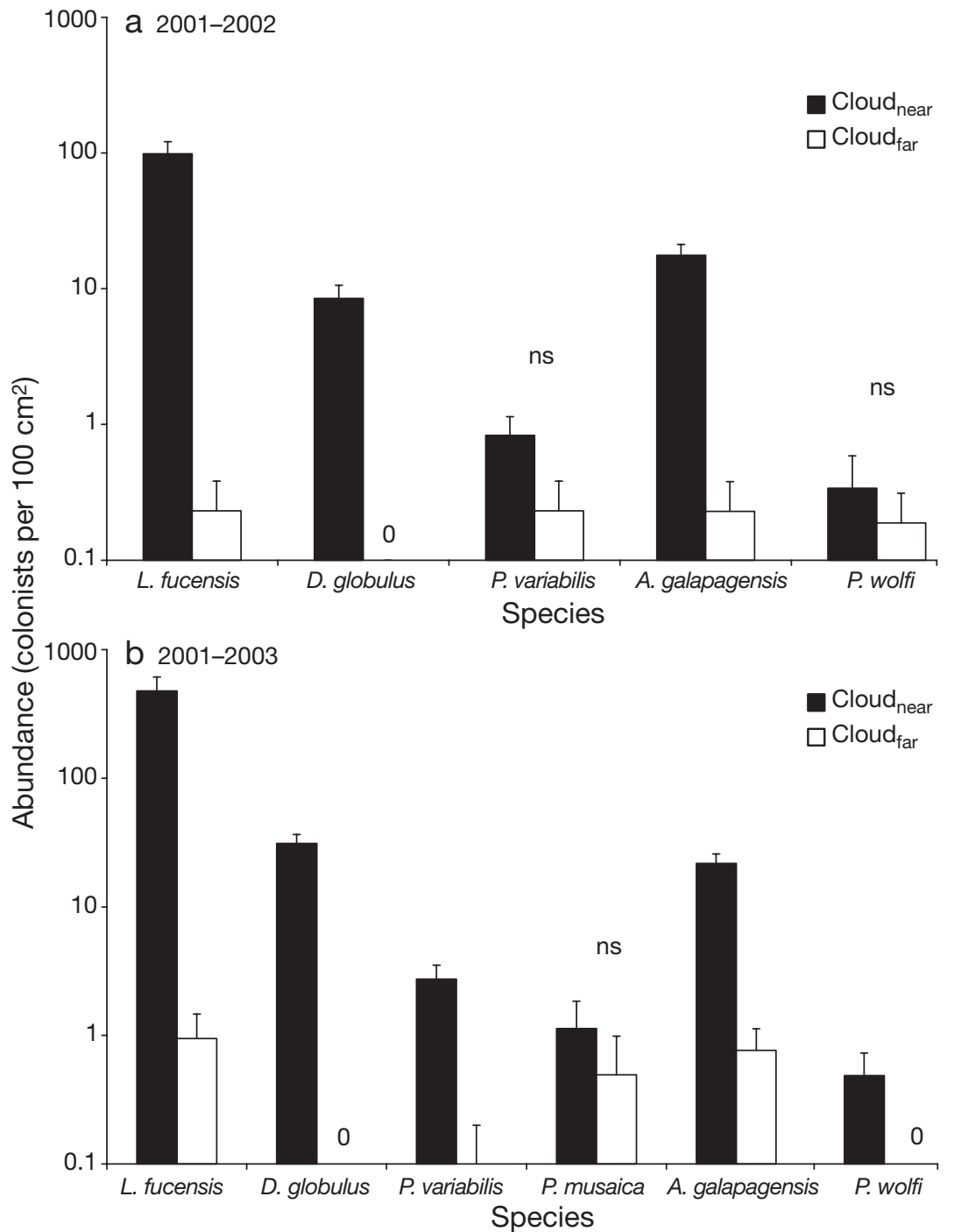

Fig. 7. Lepetodrilus fucensis, Depressigyra globulus, Provanna variabilis, Amphisamytha galapagensis, Parougia wolfi and Pyropelta musaica. Abundance of colonists (mean $+\mathrm{SE}$ ) found on basalt blocks deployed at Cloud $_{\text {near }}$ $(<1 \mathrm{~m})$ and Cloud $_{\text {far }}(<10 \mathrm{~m})$ locations from Cloud vent for (a) the 2001-2002, and (b) the 2001-2003 deployment period. ns: no significant differences; all other comparisons were significant $(\mathrm{p}<0.05)$. $\mathrm{n}$ given in Table 2 only 3 vent sites at one point in time. Hydrothermal vent species experience fluctuations in the physico-chemical characteristics of hydrothermal fluid over spatial and temporal scales (Tunnicliffe et al. 1985, Johnson et al. 1988a, 1988b, Little et al. 1988, Chevaldonne et al. 1991, Sarrazin et al. 1997, 1999), which need to be considered when comparing faunal distributions over different sites and times. Additionally, many vent fluid characters are highly correlated (Johnson et al. 1988b, 1994, Sarrazin et al. 1999, Butterfield et al. 2004; but see Luther et al. 2001). Other environmental factors may also have a significant effect on the survival of settlers and colonists of vent species, such as food and $\mathrm{O}_{2}$ availability, flow intensity, or variation in habitat complexity (Sarrazin et al. 1999). It is most likely that suites of environmental variables regulate the distributions of hydrothermal vent invertebrates, depending on the specific physiological tolerances and nutritional requirements of each species.

Colonization was always higher near than far from the vent opening, although for Provanna variabilis and Pyropelta musaica, the difference was not significant, possibly because of the low incidence of these species. Thus, close proximity to venting fluid appears critical for the successful colonization of some species (e.g. Depressigyra globulus), but not others. The presence of Amphisamytha galapagensis at both distances is not surprising, as it has been found on basaltic crusts up to $50 \mathrm{~m}$ away from a venting source (McHugh \& Tunnicliffe

Table 9. Lepetodrilus fucensis, Provanna variabilis, Amphisamytha galapagensis, Depressigyra globulus and Parougia wolfi. Pearson's correlation coefficients between environmental variables given in Table 8 (including block temperature given in Table 1) and abundances of the 5 most abundant species on basalt blocks $(n=45$, except for block temperature, where $n=32$ ). ${ }^{*} \mathrm{p}<0.05,{ }^{* *} \mathrm{p}<0.01,{ }^{* * *} \mathrm{p}<0.001$

\begin{tabular}{|c|c|c|c|c|c|c|}
\hline Species & $\mathrm{H}_{2} \mathrm{~S}$ & $\mathrm{Fe}$ & $\mathrm{Mn}$ & $\mathrm{Si}$ & $\begin{array}{l}\text { Vent } \\
\text { temp }\end{array}$ & $\begin{array}{l}\text { Block } \\
\text { temp }\end{array}$ \\
\hline \multirow{2}{*}{$\begin{aligned} \text { L. fucensis } & \text { (protoconchs) } \\
& \text { (colonists) }\end{aligned}$} & $0.344^{*}$ & 0.261 & $0.388^{* *}$ & $0.405^{* *}$ & $-0.358^{*}$ & $0.499^{* *}$ \\
\hline & 0.129 & 0.009 & 0.205 & 0.238 & $-0.497^{* *}$ & $0.452^{* *}$ \\
\hline D. globulus (protoconchs) & $0.589^{* * *}$ & $0.533^{* * *}$ & $0.608^{* * *}$ & $0.611^{* * *}$ & -0.263 & $0.505^{* *}$ \\
\hline (colonists) & $0.533^{* * *}$ & $0.489^{* *}$ & $0.578^{* * *}$ & $0.584^{* * *}$ & -0.291 & $0.630^{* * *}$ \\
\hline P. variabilis & $0.521^{* * *}$ & $0.484^{* *}$ & $0.514^{* * *}$ & $0.511^{* * *}$ & -0.142 & $0.571^{* *}$ \\
\hline A. galapagensis & $0.600^{* * *}$ & $0.544^{* * *}$ & $0.610^{* * *}$ & $0.610^{* * *}$ & -0.216 & $0.592^{* * *}$ \\
\hline P. wolfi & $-0.348^{*}$ & $-0.428^{* *}$ & -0.284 & -0.252 & $-0.306^{*}$ & -0.323 \\
\hline
\end{tabular}




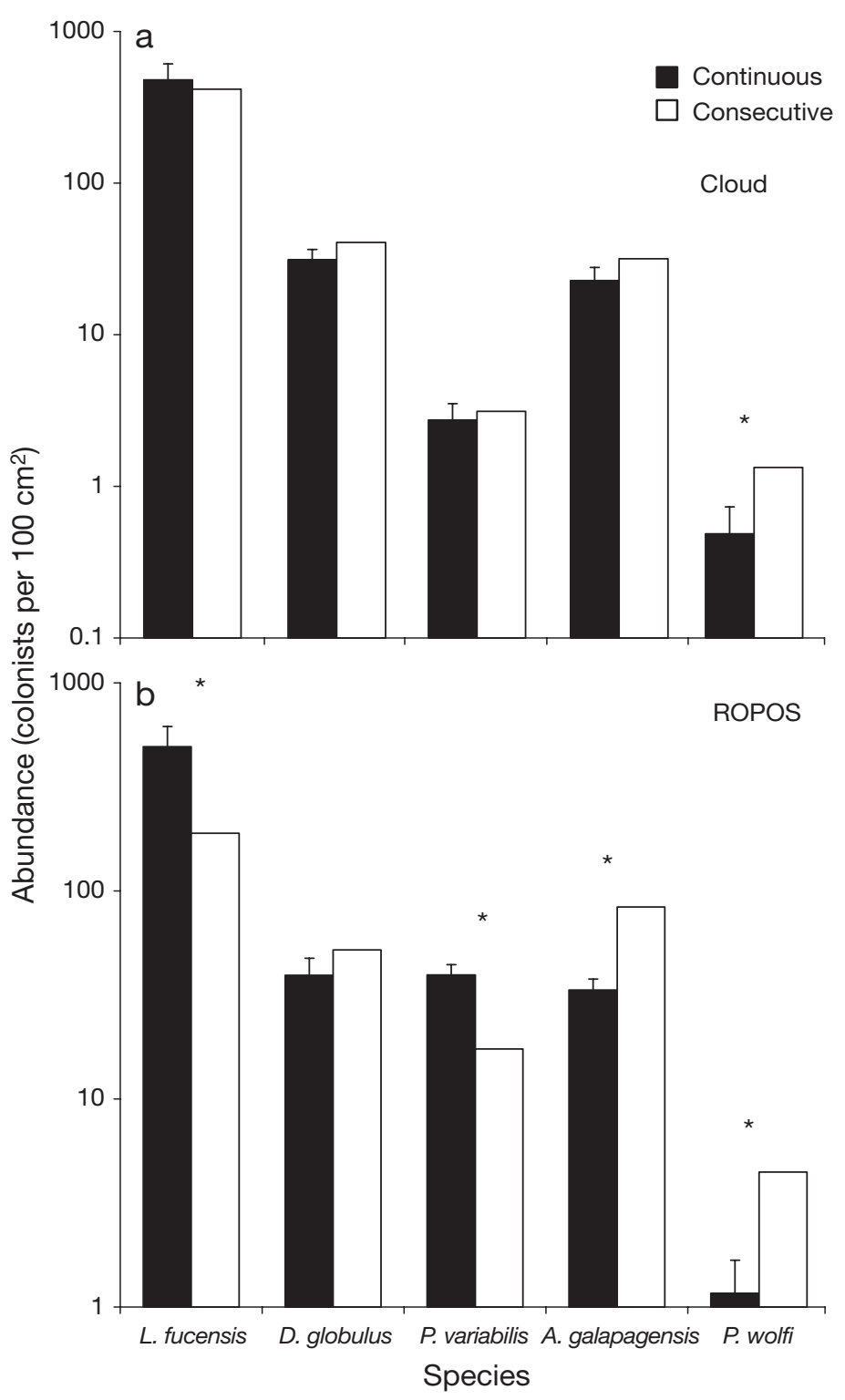

Fig. 8. Lepetodrilus fucensis, Provanna variabilis, Amphisamytha galapagensis, Depressigyra globulus and Parougia wolfi. Abundance of colonists (mean + SE) of the 5 most abundant species summed from basalt blocks deployed for two $1 \mathrm{yr}$ intervals (sum of mean number of colonists from 2001-2002 plus 2002-2003; 'consecutive') and compared to abundance of colonists on basalt blocks deployed for a 2 yr interval in 2001-2003 ('continuous') at (a) Cloud and (b) ROPOS vent sites at Axial Volcano. ${ }^{*}$ Significant difference within a species

1994). Recruitment to hard substrates outside of direct vent influence has also been recorded for species on the East Pacific Rise (Van Dover et al. 1988, Mullineaux et al. 1998, Van Dover 2002). Marcus \& Tunnicliffe (2002) documented a distinct faunal signature in peripheral habitats 5 to $6 \mathrm{~m}$ away from the venting source at Cloud, and suggested that some vent species may prefer peripheral areas as an optimal zone for foraging, since non-vent food resources may also be available. The presence of vent species on Cloud $_{\text {far }}$ blocks in our study suggests that vent influence may be exported out to $\sim 10 \mathrm{~m}$ distances, potentially increasing the amount of habitat available for colonization. However, we found few to no recent settlers on Cloud $_{\text {far }}$ blocks, implying either settlement to far vent locations is low, post-settlement survival is low, or, more likely, at this distance vent fluid concentrations are too low to support large faunal abundances.

\section{Temporal variation in settlement and colonization}

Colonization was variable between years for most species, possibly reflecting variability in settlement. At Axial vent sites, settlement of both gastropod species was higher in 2003 than in 2002. Metaxas (2004) found that near bottom $(<50 \mathrm{~cm})$ larval supply at the same sites at Axial Volcano also varied, by an order of magnitude, between 2000 and 2001. Larval supply could vary temporally due to variations in adult population abundance, especially as a result of ecological succession after an eruption (Tunnicliffe et al. 1997, Shank et al. 1998). The colonization patterns observed in this study likely reflected this variation in larval supply. For example, at Cloud vent, the increase in Lepetodrilus fucensis settler abundance observed in this study between 2002 and 2003 likely reflected the increase in the relative abundance of adult $L$. fucensis since 2000 (Marcus 2003, N. Kelly pers. obs.). Temporal variations in larval supply may also be attributed to oscillations of oceanic currents within, along, or above axial valleys or ridge crests (Thompson et al. 2003, Marsh et al. 2001).

At Axial Volcano, spatial variability in colonization among vent sites was lower after 2 yr than after 1 yr. On the Juan de Fuca Ridge, Tsurumi \& Tunnicliffe (2003) documented that $3 \mathrm{yr}$ after an eruption the composition of new vent assemblages was not distinct from that of older vents, while those 1 or 2 yr after were. In newly opened habitats (in our case, uncolonized basalt blocks), pulses of larvae may regulate vent communities over short time scales (Sarrazin et al. 1997, Tsurumi \& Tunnicliffe 2001), particularly if a homogeneous larval pool exists over km scales (Metaxas 2004). Processes operating over periods of years may obscure early patterns of colonization (Mullineaux et al. 2003). In contrast, at Endeavour, spatial patterns in the abundance of colonists remain consistent over time. The timescale of assemblage development may be different at Endeavour than at Axial vent sites, possibly due to the greater temporal stability in venting conditions at Endeavour vent sites. 
Table 10. Lepetodrilus fucensis, Provanna variabilis, Amphisamytha galapagensis, Depressigyra globulus and Parougia wolfi. One-sample Student's $t$-tests examining differences between the summed mean abundance of colonists from the consecutive 1 yr deployments (2001-2002 plus 2002-2003) and the continuous 2 yr deployment (2001-2003) for the 5 most abundant species at ROPOS and Cloud vent sites. df for all tests $=7$. $(+)$ positive interactions: summed consecutive $<$ continuous; $(-)$ negative interactions: summed consecutive $>$ continuous; $(0)$ neutral interactions: summed consecutive $=$ continuous

\begin{tabular}{|lrcccccc|}
\hline Species & \multicolumn{3}{c}{ ROPOS } & \multicolumn{3}{c|}{ Cloud } \\
& $t$ & $\mathrm{p}$ & Effect & $t$ & $\mathrm{p}$ & Effect \\
\hline L. fucensis & 2.47 & 0.043 & + & 0.46 & 0.659 & 0 \\
D. globulus & -1.55 & 0.164 & 0 & -1.76 & 0.121 & 0 \\
P. variabilis & 4.62 & 0.002 & + & -0.50 & 0.633 & 0 \\
A. galapagensis & -11.76 & $<0.001$ & - & -1.82 & 0.112 & 0 \\
$P$. wolfi & -6.43 & $<0.001$ & - & -3.48 & 0.010 & - \\
& & & & & & & \\
\hline
\end{tabular}

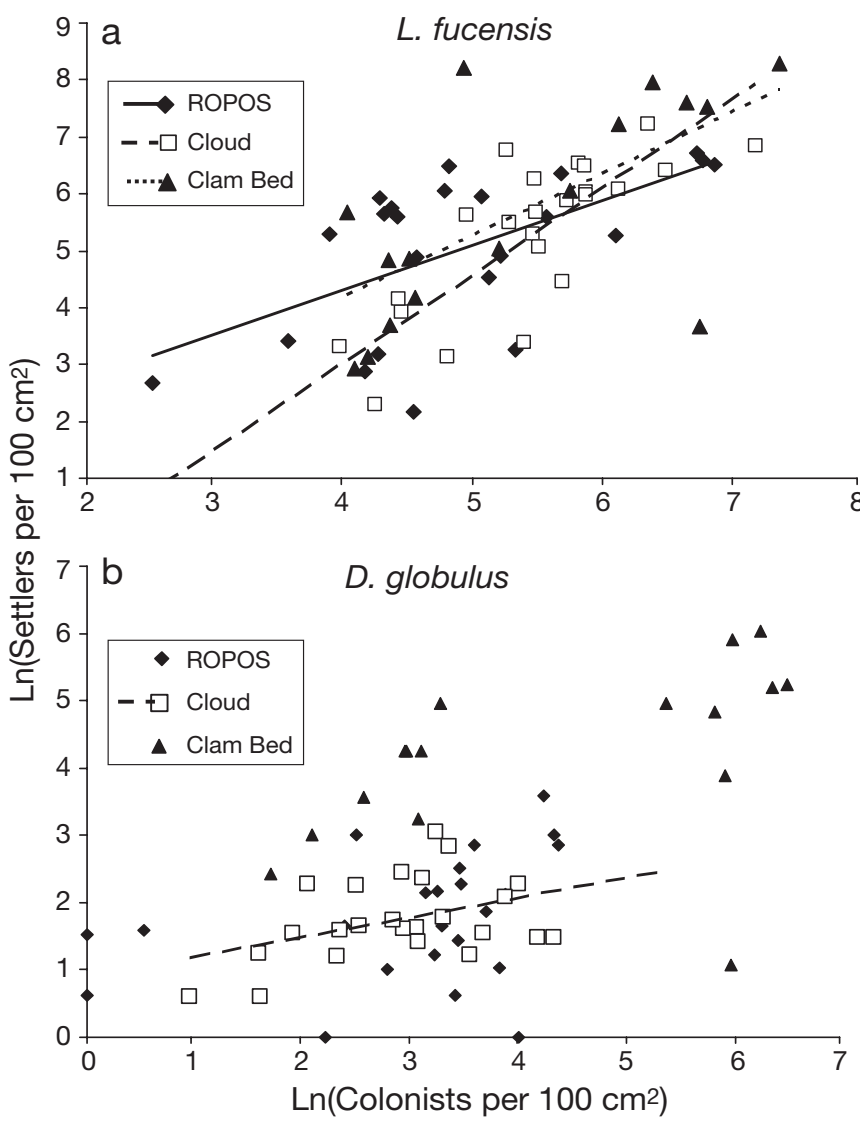

Fig. 9. Lepetodrilus fucensis and Depressigyra globulus. Relationship between settlers (S) and colonists (C) on basalt blocks deployed at ROPOS and Cloud vent sites at Axial Volcano and Clam Bed at Endeavour Segment, for (a) L. fucensis $\left[\right.$ ROPOS: $\ln (\mathrm{S}+1)=0.79 \times \ln (\mathrm{C}+1)+1.13, \mathrm{r}^{2}=0.35, \mathrm{p}=$ 0.002; Cloud: $\ln (\mathrm{S}+1)=1.56 \times \ln (\mathrm{C}+1)-3.19, \mathrm{r}^{2}=0.76, \mathrm{p}<$ 0.001; Clam Bed: $\ln (\mathrm{S}+1)=1.09 \times \ln (\mathrm{C}+1)-0.16, \mathrm{r}^{2}=0.43, \mathrm{p}=$ 0.006 ] and (b) D. globulus [ROPOS: $\ln (\mathrm{S}+1)=0.27 \times \ln (\mathrm{C}+1)+$ $0.94, \mathrm{r}^{2}=0.13, \mathrm{p}>0.05$; Cloud: $\ln (\mathrm{S}+1)=0.3 \times \ln (\mathrm{C}+1)+0.89, \mathrm{r}^{2}$ $=0.18, \mathrm{p}<0.05$; Clam Bed: $\ln (\mathrm{S}+1)=0.33 \times \ln (\mathrm{C}+1)+2.73$ $\left.r^{2}=0.20, p>0.05\right]$. Note different scales on $x$-axes

\section{Biological influences on settlement and colonization}

Intraspecific influences on colonization of hydrothermal vent species were evident for 4 of the 5 species examined. Positive interactions, which we interpreted as gregarious settlement, were inferred for Lepetodrilus fucensis and Provanna variabilis. Gregarious settlement may in part explain the large abundance of L. fucensis at Juan de Fuca Ridge vent sites (Bates et al. 2005). Settlement cues produced by conspecifics or related species have been suggested for promoting vestimentiferan colonization on the East Pacific Rise (Shank et al. 1998, Mullineaux et al. 2000, Hunt et al. 2004). The use of biogenic cues by larvae, rather than the instantaneous physico-chemical conditions, would provide an integrated measure of habitat suitability, implying that favourable environmental conditions have persisted at least as long as the age of the species producing it (Mullineaux et al. 2000). P. variabilis develops directly within egg cases laid by the parent on basalt surfaces, although there may be a short planktonic stage before the onset of benthic life (A. Warén, pers. comm.). These egg cases may be laid in aggregations, and juveniles would emerge in a gregarious pattern. While a significant, although weak, relationship between settlers and colonists existed for Depressigyra globulus at Cloud vent site, there were no other indications of intraspecific biological interactions influencing colonization for this species. Thus, we suggest pre-settlement factors, such as mortality of larvae in the water column during dispersal, larval behaviour when encountering a settlement cue, or variations in larval supply, are influencing subsequent settlement and colonization for $D$. globulus.

Negative, inhibitory interactions, which we interpreted as post-settlement mortality, appear to be regulating colonization patterns of the polychaetes Amphisamytha galapagensis and Parougia wolfi. A. galapagensis is a sessile deposit feeder (McHugh \& Tunnicliffe 1994) and competition for substratum space and/or food resources could result in post-settlement mortality. At Juan de Fuca vents, interspecific competition for food resources has been demonstrated in regulating the distributions of another polychaete, Paralvinella sp. (Levesque et al. 2003). Colonists of $A$. galapagensis were often found on or within the mucus tubes of larger individuals (McHugh \& Tunnicliffe 1994, N. Kelly pers. obs.), suggesting there may be some positive effect conferred by adults on colonist survival. However, large abundances of mobile gastropods could accidentally bulldoze small A. galapagensis colonists that settle randomly, and this high post-settlement mortality would result in juveniles being more frequently observed in close association with adult conspecifics. Bulldozing of sessile recruits 
by gastropods has been documented at low temperature vents on the East Pacific Rise (Micheli et al. 2002, Mullineaux et al. 2003). P. wolfi is a small predator, and its biology is mostly unknown (Blake \& Hilbig 1990), but competition for prey causing starvation or forced migration from blocks, or vulnerability to other predators, could explain the lower abundances on continuously deployed blocks. Van Dover et al. (1988) suggested predation by fish, crabs and other organisms was responsible for the immaturity of colonists on slate panels after 3 yr of deployment. Large predatory polychaetes (Nereis piscesae and polynoid polychaetes) and large mobile crustaceans (Munidopsis alvisca, Macroregonia macrochira) were also found on or near our basalt blocks.

Mean abundance of Lepetodrilus fucensis, Provanna variabilis, Amphisamytha galapagensis, and Parougia wolfi were all slightly higher at ROPOS than at Cloud, and intraspecific interactions occurred more frequently at ROPOS than at Cloud. These results suggest that an 'abundance threshold' may be required for intraspecific interactions that regulate vent faunal abundances at Juan de Fuca vent sites to take effect. For example, there may need to be enough individuals present at a vent to produce a cue to facilitate gregarious settlement, or enough individuals present to reduce the abundance of subsequent colonists.

\section{CONCLUSIONS}

This is the first study to quantify the scales of spatial and temporal variability in settlement and colonization of hydrothermal vent species on the Juan de Fuca Ridge. Through the deployment of basalt blocks, we demonstrated that for most species, variation in settlement and colonization is greater among vent sites (over $\mathrm{km}$ scales) than between ridge segments (over $100 \mathrm{~km}$ scales), and within a vent site. Environmental properties of the hydrothermal vent fluid, most notably temperature and dissolved $\mathrm{H}_{2} \mathrm{~S}$, appear to be important factors influencing this variation among spatially separated vent sites. However, for some species, the initial patterns of variation in colonization can be obscured over longer periods, in part due to intraspecific biological interactions, such as gregarious settlement and post-settlement mortality, particularly when faunal abundances are high. In combination, our results suggest that the variability in settlement and colonization of hydrothermal vent species is regulated primarily by a species-specific response to the varying environmental conditions at a particular vent, and secondarily by biological interactions that further alter subsequent colonization patterns. Our findings indicate that the hypotheses previously erected on the factors that reg- ulate adult populations on the Juan de Fuca Ridge (Sarrazin et al. 1997, 1999), also hold for settlers and colonizers. Increased temporal resolution and simultaneous measures of vent fluid properties with invertebrate colonization would identify the specific inductive and causative factors influencing early-life history stages of species in these habitats.

Acknowledgements. We thank the crews of the RV 'Thomas G. Thompson', CCGS John P. Tully, and ROPOS for their assistance during deployment and recovery of many sets of basalt blocks. We also thank chief scientists V. Tunnicliffe, K. Juniper, B. Embley, W. Chadwick, and J. Delaney for their patience and willingness to conduct these experiments during cruises with many time constraints. A. Bates, J. Csotonyi, A. Ortmann and G. Yahel helped with block recovery and provided moral support aboard ship. A. Warén provided valuable information on gastropod identification. B. Schofield helped design and construct blocks and frames. Finally, we thank R. Scheibling and 3 anonymous reviewers for useful critical reviews of an earlier version of this manuscript. This research was supported by a NSERC PGS D Scholarship and Izaak Walton Killam Memorial Scholarship to N.K., NSERC Discovery and CRO grants to A.M., the NOAA/PMEL Vents Program (PMEL contribution \#3048), and by the Joint Institute for the Study of the Atmosphere and Ocean (JISAO contribution \#1389) under NOAA Cooperative Agreement No. NA117RJ1232.

\section{LITERATURE CITED}

Bates AE, Tunnicliffe V, Lee RW (2005) Role of thermal conditions in habitat selection by hydrothermal vent gastropods. Mar Ecol Prog Ser 305:1-15

Berg CJ Jr (1985) Reproductive strategies of mollusks from abyssal hydrothermal vent communities. Bull Biol Soc Wash 6:185-197

Blake JA, Hilbig B (1990) Polychaeta from the vicinity of deep-sea hydrothermal vents in the eastern pacific. II. New species and records from the Juan de Fuca and Explorer Ridge systems. Pac Sci 44:219-253

Butterfield DA, McDuff RE, Mottl MJ, Lilley MD, Lupton JE, Massoth GJ (1994) Gradients in the composition of hydrothermal fluids from the Endeavour segment vent field: phase separation and brine loss. J Geophys Res 99: 9561-9583

Butterfield DA, Lilley MD, Huber JA, Baross JA, Roe KK, Embley RW, Massoth GJ (2004) Mixing, reaction, and microbial activity in the sub-seafloor revealed by temporal and spatial variation in diffuse flow vents at Axial Volcano. In: Wilcock WSD, DeLong EF, Kelley DS, Baross JA, Cary SC (eds) The sub-seafloor biosphere at mid-ocean ridges. AGU Geophysical Monograph 144. American Geophysical Union, Washington, DC, p 269-289

Chevaldonne P, Desbruyeres D, Le Haitre M (1991) Timeseries of temperature from three deep-sea hydrothermal vent sites. Deep-Sea Res 38:1417-1430

Glickson DA, Kelley DS, Delayne JR (2007) Geology and hydrothermal evolution of the Mothra Hydrothermal Field, Endeavour Segment, Juan de Fuca Ridge. Geochem Geophys Geosyst 8, doi: 10.1029/2007GC001588

Hunt HL, Metaxas A, Jennings RM, Halanych KM, Mullineaux LS (2004) Testing biological control of colonization by vestimentiferan tubeworms at deep-sea 
hydrothermal vents (East Pacific Rise, $95^{\circ} 0^{\prime} \mathrm{N}$ ). Deep-Sea Res I 51:225-234

Jannasch HW (1995) Microbial interactions with hydrothermal fluids. In: Humphris S (ed) Seafloor hydrothermal systems: physical, chemical, biological, and geological interactions. American Geophysical Union, Washington, DC, p 273-296

Johnson KS, Beehler CL, Sakamoto-Arnold CM, Childress JJ (1986) In situ measurements of chemical distributions in a deep-sea hydrothermal vent field. Science 231:1139-1141

Johnson KS, Childress JJ, Beehler CL (1988a) Short-term temperature variability in the Rose Garden hydrothermal vent field: an unstable deep-sea environment. Deep-Sea Res 35:1711-1721

Johnson KS, Childress JJ, Hessler RR, Sakamoto-Arnold CM, Beehler CL (1988b) Chemical and biological interactions in the Rose Garden hydrothermal vent field, Galapagos spreading center. Deep-Sea Res 35:1723-1744

Johnson KS, Childress JJ, Beehler CL, Sakamoto CM (1994) Biogeochemistry of hydrothermal vent mussel communities: the deep-sea analogue to the intertidal zone. DeepSea Res 41:993-1011

Karl DM, Wirsen CO, Jannasch HW (1980) Deep-sea primary production at the Galapagos hydrothermal vents. Science 207:1345-1347

Lavelle JW, Cannon GA (2001) On subinertial oscillations trapped by the Juan de Fuca Ridge, northeast Pacific. J Geophys Res 106:31099-31116

Levesque C, Juniper SK, Marcus J (2003) Food resource partitioning and competition among alvinellid polychaetes of Juan de Fuca Ridge hydrothermal vents. Mar Ecol Prog Ser 246:173-182

Lilley MD, Butterfield DA, Olson EJ, Lupton JE, Macko SA, McDuff RE (1993) Anomalous $\mathrm{CH}_{4}$ and $\mathrm{NH}^{4+}$ concentrations at an unsedimented mid-ocean-ridge hydrothermal system. Nature 364:45-47

Little SA, Stolzenbach KD, Grassle FJ (1988) Tidal current effects on temperature in diffuse hydrothermal flow: Guaymas Basin. Geophys Res Lett 15:1491-1494

Luther GW III, Rozan TF, Taillefert M, Nuzzlo DB, Di Meo C, Shank TM, Lutz RA, Cary SC (2001) Chemical speciation drives hydrothermal vent ecology. Nature 410:813-816

Lutz RA, Jablonski D, Rhoads DC, Turner RD (1980) Larval dispersal of a deep-sea hydrothermal vent bivalve from the Galapagos Rift. Mar Biol 57:127-133

Marcus J (2003) Community ecology of hydrothermal vents at Axial Volcano, Juan de Fuca Ridge, Northeast Pacific. PhD dissertation, University of Victoria

Marcus J, Tunnicliffe V (2002) Living on the edges of diffuse vents on the Juan de Fuca Ridge. Cah Biol Mar 43:263-266

Marsh AG, Mullineaux LS, Young CM, Manahan DT (2001) Larval dispersal potential of the tubeworm Riftia pachyptila at deep-sea hydrothermal vents. Nature 411:77-80

McHugh D, Tunnicliffe V (1994) Ecology and reproductive biology of the hydrothermal vent polychaete Amphisamytha galapagensis (Ampharetidae). Mar Ecol Prog Ser 106:111-120

Metaxas A (2004) Spatial and temporal patterns in larval supply at hydrothermal vents on the northeast Pacific Ocean. Limnol Oceanogr 49:1949-1956

Micheli F, Peterson CH, Mullineaux LS, Fisher CR, Mills SW, Sancho G, Johnson GA, Lenihan HS (2002) Predation structures communities at deep-sea hydrothermal vents. Ecol Monogr 72:365-382

Mullineaux LS, France SC (1995) Dispersal mechanisms of deep-sea hydrothermal vent fauna. Geophys Monogr 91: 408-424

Editorial responsibility: Howard Browman (Associate Editorin-Chief) Storebø, Norway
Mullineaux LS, Mills SW, Goldman E (1998) Recruitment variation during a pilot colonization study of hydrothermal vents. Deep-Sea Res II 45:441-464

Mullineaux LS, Fisher CR, Peterson CH, Schaeffer SW (2000) Tubeworm succession at hydrothermal vents: use of biogenic cues to reduce habitat selection error? Oecologia 123:275-284

Mullineaux LS, Peterson CH, Micheli F, Mills SW (2003) Successional mechanism varies along a gradient in hydrothermal fluid flux at deep-sea vents. Ecol Monogr 73:523-542

Rittschof D, Forward RB Jr, Cannon G, Welch JM and 7 others (1998) Cues and context: larval responses to physical and chemical cues. Biofouling 12:31-44

Sarrazin J, Juniper SK (1999) Biological characteristics of a hydrothermal edifice mosaic community. Mar Ecol Prog Ser 185:1-19

Sarrazin J, Robigou V, Juniper SK, Delaney JR (1997) Biological and geological dynamics over four years on a hightemp sulfide structure at the Juan de Fuca Ridge hydrothermal observatory. Mar Ecol Prog Ser 153:5-24

Sarrazin J, Juniper SK, Massoth G, Legendre P (1999) Physical and chemical factors influencing species distributions on hydrothermal sulfide edifices of the Juan de Fuca Ridge, northeast Pacific. Mar Ecol Prog Ser 190:89-112

Shank TM, Fornari DJ, Von Damm KL, Lilley MD, Haymon RM, Lutz RA (1998) Temporal and spatial patterns of biological community development at nascent deep-sea hydrothermal vents. Deep-Sea Res II 45:465-515

Thompson RE, Mihaly SF, Ravinovich AB, McDuff RE, Veirs SR, Stahr FR (2003) Constrained circulation at Endeavour ridge facilitates colonozation by vent larvae. Nature 424:545-549

Tsurumi M, Tunnicliffe V (2001) Characteristics of a hydrothermal vent assemblage on a volcanically active segment of Juan de Fuca Ridge, northeast Pacific. Can J Fish Aquat Sci 58:530-542

Tsurumi M, Tunnicliffe V (2003) Tubeworm-associated communities at hydrothermal vents on the Juan de Fuca Ridge, northeast Pacific. Deep-Sea Res I 50:611-629

Tunnicliffe V, Juniper SK (1990) Dynamic character of the hydrothermal vent habitat and the nature of the sulphide chimney fauna. Prog Oceanogr 24:1-13

Tunnicliffe V, Juniper SK, de Burgh ME (1985) The hydrothermal vent community on Axial Seamount, Juan de Fuca Ridge. Bull Biol Soc Wash 6:453-464

Tunnicliffe V, Desbruyeres D, Jollivet D, Laubier L (1993) Systematic and ecological characteristics of Paralvinella sulfincola Desbruyeres and Laubier, a new polychaete (family Alvinellidae) from northeast Pacific hydrothermal vents. Can J Zool 71:286-297

Tunnicliffe V, Embley RW, Holden JF, Butterfield DA, Massoth BJ, Juniper SK (1997) Biological colonization of new hydrothermal vents following an eruption on Juan de Fuca Ridge. Deep-Sea Res I 44:1627-1644

Van Dover CL (2002) Community structure of mussel beds at deep-sea hydrothermal vents. Mar Ecol Prog Ser 230: 137-158

Van Dover CL, Berg CJ Jr, Turner RD (1988) Recruitment of marine invertebrates to hard substrates at deep-sea hydrothermal vents on the East Pacific Rise and Galapagos spreading center. Deep-Sea Res 35:1833-1849

Zal F, Jollivet D, Chevaldonne P, Desbruyeres D (1995) Reproductive biology and population structure of the deep-sea hydrothermal vent worm Paralvinella grasslei (Polychaeta:Alvinellidae) at $13^{\circ} \mathrm{N}$ on the East Pacific Rise. Mar Biol 122:637-648

Submitted: February 18, 2007; Accepted: June 19, 2007

Proofs received from author(s): July 9, 2007 